\title{
AY-WB Phytoplasma Secretes a Protein That Targets Plant Cell Nuclei
}

\author{
Xiaodong Bai, ${ }^{1}$ Valdir R. Correa, ${ }^{1}$ Tania Y. Toruño, ${ }^{1}$ El-Desouky Ammar, ${ }^{1}$ Sophien Kamoun, ${ }^{2,3}$ and \\ Saskia A. Hogenhout ${ }^{1,4}$ \\ ${ }^{1}$ Department of Entomology and ${ }^{2}$ Department of Plant Pathology, The Ohio State University-OARDC, Wooster 44691, \\ U.S.A.; ${ }^{3}$ Sainsbury Laboratory Norwich Research Park, Norwich, NR4 7UH, U.K.; ${ }^{4}$ Department of Disease and Stress \\ Biology, The John Innes Centre, Norwich Research Park, Norwich, NR4 7UH, U.K.
}

Submitted 24 June 2008. Accepted 31 August 2008.

\begin{abstract}
The fully sequenced genome of aster yellows phytoplasma strain witches' broom (AY-WB; Candidatus Phytoplasma asteris) was mined for the presence of genes encoding secreted proteins based on the presence of $\mathrm{N}$-terminal signal peptides (SP). We identified 56 secreted AY-WB proteins (SAP). These SAP are candidate effector proteins potentially involved in interaction with plant and insect cell components. One of these SAP, SAP11, contains an N-terminal SP sequence and a eukaryotic bipartite nuclear localization signal (NLS). Transcripts for SAP11 were detected in AYWB-infected plants. Yellow fluorescence protein (YFP)tagged SAP11 accumulated in Nicotiana benthamiana cell nuclei, whereas the nuclear targeting of YFP-tagged SAP11 mutants with disrupted NLS was inhibited. The nuclear transport of YFP-SAP11 was also inhibited in $N$. benthamiana plants in which the expression of importin $\alpha$ was knocked down using virus-induced gene silencing (VIGS). Furthermore, SAP11 was detected by immunocytology in nuclei of young sink tissues of China aster plants infected with AY-WB. In summary, this work shows that AY-WB phytoplasma produces a protein that targets the nuclei of plant host cells; this protein is a potential phytoplasma effector that may alter plant cell physiology.
\end{abstract}

Additional keywords: insect vector, leafhopper, mollicute, secdependent secretion, virulence protein.

The ability of pathogens to infect hosts is dependent on the effectiveness of virulence factors, often called effectors, secreted by the microbe. The effectors are sophisticated proteins that share sequence, functional, or structural features with proteins of the usually eukaryotic host and can interfere with many host cell processes, such as intracellular trafficking, gene expression, and defense responses (Desveaux et al. 2006). In recent years, much progress has been made in the functional characterization of effectors of plant pathogens, particularly gramnegative bacterial and filamentous pathogens (Buttner and

Corresponding author: Saskia A. Hogenhout;

E-mail: saskia.hogenhout@bbsrc.ac.uk

Current address of V. R. Correa: Department of Horticulture and Crop Sciences, The Ohio State University-OARDC, Wooster 44691, U.S.A.

Current address of T. Y. Toruño: Plant Science Initiative, The George W. Beadle Center, University of Nebraska, Lincoln 68588-0660, U.S.A.

* The $e$-Xtra logo stands for "electronic extra" and indicates that four supplemental figures are published online.
Bonas 2006; Chisholm et al. 2006; Grant et al. 2006; Kamoun 2006; Mudgett 2005; Toth and Birch 2005). The majority of these effectors interfere with various steps in basal immune cascades triggered in plants upon recognition of, for example, pathogen-associated molecular patterns (PAMPs), such as flagellin and lipopolysaccharides. Some effectors are recognized by host cells and trigger rapid programmed cell death responses that prevent further spread of pathogens (Mackey and McFall 2006; Vinatzer et al. 2006).

Phytoplasmas are small ( 0.2 to $0.8 \mu \mathrm{m}$ in diameter) pleiomorphic bacteria that compose a large group of highly diverse phytopathogenic bacteria within the class Mollicutes (Bertaccini 2007; Garnier et al. 2001; Hogenhout et al. 2008; Lee et al. 2000). Mollicutes have evolved from gram-positive ancestors by genome reductions and the loss of outer peptidoglycan cell walls (Weisburg et al. 1989; Woese 1987). Other mollicutes are mycoplasmas, ureaplasmas, and spiroplasmas, which are invasive pathogens of humans, vertebrate and invertebrate animals, and plants (Razin et al. 1998). Phytoplasmas have been identified in over 1,000 plant species worldwide (Streten and Gibb 2006) and are responsible for plant diseases with significant economic impacts, including relatively recent disease outbreaks in, for instance, grapevines (Angelini et al. 2006) and maize (Duduk and Bertaccini 2006; Jovic et al. 2007) in Europe.

One of the challenges at present is to functionally characterize effector proteins of gram-positive and related bacterial pathogens of plants. Gram-negative bacterial pathogens and symbionts typically have type III and type IV secretion systems that form hollow tubes (Aly and Baron 2007; Jin and He 2001) through which effectors travel from the bacterial cytosol directly into the cytosol of host cells (Angot et al. 2007; Ding et al. 2003; Grant et al. 2006). In contrast, gram-positive bacteria seem to require predominantly the Sec-dependent pathway for delivery of virulence proteins (Hogenhout and Loria 2008), as has been shown for the human pathogen Streptococcus pyogenes (Rosch and Caparon 2005). S. pyogenes can secrete host cell pore-forming proteins that provide access for effector proteins to the host cell cytoplasm (Bricker et al. 2002; Madden et al. 2001; Rosch and Caparon 2005). The pathogenicity factor Pat-1, a putative serine protease, of the gram-positive plant pathogen Clavibacter michiganensis subsp. michiganensis, also has a signal peptide sequence for Sec-dependent secretion (Burger et al. 2005). Phytoplasmas have a functional Sec-dependent secretion system for release of mature secreted proteins into the extracellular environment (Barbara et al. 2002; Kakizawa et al. 2001, 2004). Interestingly, several bacteria, including Streptomyces spp. and the mollicutes (spiroplasmas and phytoplasmas), are located intracellularly in plants (Ammar 
and Hogenhout 2006; Hogenhout et al. 2008; Loria et al. 2006) and, hence, can deliver their proteins directly inside the cell without the need of a specialized injection system such as the type III secretion system.

The majority of virulence proteins of gram-positive bacteria appear to locate on mobile DNA elements such as transposons and plasmids (Hogenhout and Loria 2008). Three Streptomyces spp. possess large mobile pathogenicity islands encoding genes for the biosynthesis of thaxtomin, an inhibitor of cellulose biosynthesis, and a necrogenic protein (Bukhalid et al. 1998; Healy et al. 2000; Loria et al. 2006). The complete genome sequence of aster yellows phytoplasma strain witches' broom (AY-WB) revealed the presence of large gene clusters of approximately $20 \mathrm{~kb}$ in size that have the characteristics of composite transposons and were called potential mobile units (PMU) (Bai et al. 2006). These PMU were also identified in other phytoplasmas (Bai et al. 2006; Hogenhout et al. 2008). The PMU and DNA elements that resemble PMU contain genes for candidate virulence proteins (Bai et al. 2006; Hogenhout et al. 2008).

Phytoplasmas are introduced into the phloem by insects, mainly leafhoppers, planthoppers, and psyllids (Weintraub and Beanland 2006), and replicate intracellularly in their plant and insect hosts (Ammar and Hogenhout 2006; Garnier et al. 2001; Hogenhout et al. 2008; Marzachi and Bosco 2005). In plants, they remain mainly restricted to the sieve elements and move throughout the plant by passing through the sieve pores (Rudzinska-Langwald and Kaminska 1999). AY-WB and other phytoplasmas are in direct contact with the cytoplasm of anucleated mature phloem cells and of nucleated protophloem cells of sink tissues (Ammar and Hogenhout 2006). Phytoplasmas, including AY-WB, induce distinctive symptoms, such as phyllody (differentiation of floral parts into leafy structures) and witches' broom (clustering and proliferation of shoots), that are most prominent in plant sink tissues (Bertaccini 2007) and suggest that phytoplasmas interfere with fundamental cellular and developmental pathways in plants (Hogenhout and Loria 2008; Hogenhout et al. 2008).

Thus far, among the mollicutes, research has mainly focused on the characterization of cell surface proteins, such as adhesins and lipoproteins of mycoplasmas and spiroplasmas (Balish 2006; Berho et al. 2006; Killiny et al. 2006; Rottem 2003). Suzuki and associates (2006) demonstrated that cell-surface membrane proteins of phytoplasmas are also involved in infection of the insect host. However, few studies have focused on mollicute proteins that are transported across the single microbial membrane and, thus, directly released into the host cytoplasmic environment. Indeed, it is not known what happens after adherence of mycoplasmas and other mollicutes to host cells. The first mycoplasma toxin with classical toxin-like activities has only recently been reported (Kannan and Baseman 2006).

Because of the inability to culture phytoplasmas in cell-free media and the lack of genetic tools, research progress to better understand the interaction of phytoplasmas with plant or insect hosts has moved slowly. Nevertheless, the availability of the complete genome sequences of four phytoplasmas offers unprecedented opportunities for investigating these organisms and the perturbations they cause in plants. These four phytoplasmas are Onion yellows phytoplasma strain M (OY-M) (Oshima et al. 2004) and AY-WB (Bai et al. 2006) that belong to Candidatus Phytoplasma asteris (previously known as the Aster Yellows 16SrI group or Aster Yellows clade), one strain of $\mathrm{Ca}$. Phytoplasma australiense (subgroup tuf-Australia I; rpA) (Tran-Nguyen et al. 2008), and the apple proliferation disease agent $\mathrm{Ca}$. Phytoplasma mali (Kube et al. 2008). AY-WB belongs to subgroup 16SrIA and OY-M to subgroup 16SrIB within $\mathrm{Ca}$. Phytoplasma asteris (Zhang et al. 2004). The disclosure of these four complete phytoplasma genomes made it possible to identify genes that are likely to have roles in phytoplasma-host interactions.

We hypothesized that phytoplasmas secrete effector proteins that target nuclei and reprogram development and modulate defenses of host plants. In this study, we used a combination of genome-wide bioinformatics and subsequent functional analyses to identify candidate effector proteins of phytoplasma strain AY-WB. Here, we describe the discovery of one AY-WB effector candidate, named secreted AY-WB protein 11 (SAP11), which accumulates in cellular nuclei of host plants infected by AY-WB.

\section{RESULTS}

Mining the AY-WB genome for candidate effector proteins.

Proteins secreted via the Sec-dependent pathway have N-terminal signal peptide (SP) sequences. SP are generally between 20 and 50 amino acids in length and are composed of a positively charged region of approximately 5 amino acids, followed by a hydrophobic region of 7 to 15 amino acids and an uncharged region of 3 to 7 polar amino acids. We used the SignalP v3.0 program (Bendtsen et al. 2004; Menne et al. 2000; Schneider and Fechner 2004) to identify putative AY-WB effector proteins secreted via the Sec-dependent pathway. This program uses a hidden Markov model (HMM) algorithm to predict the presence of the charged, hydrophobic, and polar regions in the correct order and lengths in the N-terminal region of proteins. SignalP also includes a neural networks (NN) algorithm to predict SP cleavage sites (Nielsen et al. 1997). The combination of these two algorithms generally gives a solid prediction for the presence of $\mathrm{N}$-terminal SP sequences in the majority of secreted proteins as previously shown for the oomycete pathogen Phytophthora (Torto et al. 2003). Compared with SignalP v2, SignalP v3 has an increased cleavage site prediction for eukaryotes and gram-negative and gram-positive bacteria (Bendtsen et al. 2004).

The SignalP program has been trained for predicting SP of gram-negative and gram-positive bacterial proteins. However, mollicutes have different membrane compositions compared with most other bacteria (Razin et al. 1998). Therefore, we considered it necessary to determine whether SignalP v3.0 can also successfully predict the presence of SP in mollicute proteins. We assembled a dataset containing 369 mollicute protein sequences that includes 46 proteins for which secretion was experimentally verified (Edman et al. 1999) and 323 metabolic cytoplasmic proteins based on annotations in the SwissProt database. The SignalP program predicted the presence of SP for 43 of 46 experimentally verified secreted proteins. These 43 proteins had an HMM score $>0.85$ and a cleavage site predicted by NN between 20 and 40 amino acids (Supplementary Fig. S1). On the other hand, none of the cytoplasmic proteins had a predicted cleavage site and all but one sequence had an HMM score $<0.4$. Thus, these data indicate that SignalP v3.0 can detect the presence of N-terminal SP in the majority of mollicute proteins and, therefore, can be used to predict secreted AY-WB proteins.

In order to identify secreted AY-WB proteins, the 693 deduced protein sequences of the approximately 706-kb chromosome and four plasmids (Bai et al. 2006) were run through a customized pipeline (Fig. 1). Based on an HMM score $>0.5$ and a predicted cleavage site between 20 and 50 amino acids, we identified 76 proteins with predicted SP. The vast majority of the 76 proteins had an HMM score $>0.9$ and a predicted cleavage site between 20 and 40 (Tables 1 and 2), similar to the experimentally verified mollicute secreted proteins. 
Pipeline

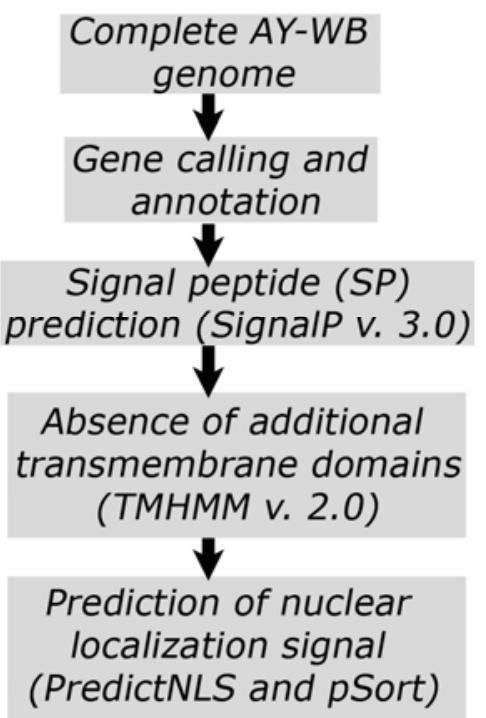

Results

\section{One chromosome and 4 plasmids}

\section{3 deduced protein sequences}

\section{6 proteins with SP}

\section{6 candidate secreted $A Y-W B$ proteins (SAP)}

\section{SAP with NLS}

Of the 76 proteins, 20 contain predicted transmembrane regions in addition to the SP (Table 1) and, hence, are likely to remain attached to the AY-WB membrane after secretion. Several of these have one transmembrane domain that is located toward the middle (AYWB_414) or at the carboxy terminal end (AYWB_016, AYWB_395, AYWB_432, AYWB_599, and AYWB_pIV04) of proteins, suggesting that major portions of these proteins are located extracellularly on the phytoplasma surface or may target the membranes of host cells similarly to pore-forming proteins of various pathogenic bacteria (Bricker et al. 2002; Madden et al. 2001; Mueller et al. 2008). Most of these are hypothetical proteins for which no functions have yet been ascribed. However, AYWB_599 is highly similar in sequence percentage to phytoplasma antigenic membrane proteins (Amps) that have cleavable SP sequences (Barbara et al. 2002).

The remaining 56 proteins do not have transmembrane regions after cleavage of the SP and, therefore, were predicted to be soluble proteins released into the extracellular environment of AY-WB. These 56 proteins were named secreted AY-WB proteins (SAP) and were assigned numbers (Table 2). As was the case for the 20 predicted extracellular membrane proteins, most of the $56 \mathrm{SAP}$ are hypothetical proteins with no known functions. However, our predictions were validated by the presence of sequences similar to five solute-binding proteins

Fig. 1. Annotation pipeline for the identification of aster yellows phytoplasma strain witches' broom (AY-WB) extracellular proteins.

Table 1. Predicted aster yellows phytoplasma strain witches' broom (AY-WB) secreted membrane proteins (20 in total)

\begin{tabular}{|c|c|c|c|c|c|c|c|c|c|}
\hline $\begin{array}{l}\text { AY-WB } \\
\text { gene }^{\text {a }}\end{array}$ & $\begin{array}{l}\text { Length } \\
{\text { (aa })^{b}}^{\text {b }}\end{array}$ & $\begin{array}{l}\text { MW } \\
(\mathbf{D a})^{\mathbf{c}}\end{array}$ & $\mathbf{I P}^{\mathbf{d}}$ & $\begin{array}{c}\text { SP } \\
\text { score }^{\mathrm{e}}\end{array}$ & $\begin{array}{l}\text { Cleavage } \\
\text { site }^{\mathrm{f}}\end{array}$ & $\begin{array}{l}\text { Cleavage } \\
\text { score }^{\text {con }}\end{array}$ & $\begin{array}{l}\text { No. of TM } \\
\text { domains }^{h}\end{array}$ & Annotation ${ }^{a}$ & $\begin{array}{l}\text { OY-M } \\
\text { protein }\end{array}$ \\
\hline 006 & 849 & 96,038 & 7.74 & 0.718 & 40 & $0.419 *$ & $\begin{array}{l}\mathrm{SP}+1 \mathrm{TM} \\
(\mathrm{o} 65-87 \mathrm{i})^{*}\end{array}$ & Exopolyphosphatase-related protein & 39938498 \\
\hline 013 & 185 & 20,803 & 9.44 & 0.988 & 42 & 0.472 & $\mathrm{SP}+4 \mathrm{TM}$ & Cons. Hyp. Protein & 39938505 \\
\hline 016 & 1,024 & 120,099 & 9.41 & 0.756 & 43 & $0.608^{*}$ & $\begin{array}{l}\mathrm{SP}+1 \mathrm{TM} \\
(\mathrm{o} 987-1009 \mathrm{i})^{*}\end{array}$ & Cons. Hyp. Protein & 39938613 \\
\hline 053 & 215 & 24,325 & 8.09 & 0.954 & 33 & 0.710 & $\mathrm{SP}+5 \mathrm{TM}$ & $\begin{array}{l}\text { pgsA, CDP-diacylglycerol- 3-phosphate-3- } \\
\text { phosphatidyl-transferase (EC 2.7.8.5) }\end{array}$ & 39939204 \\
\hline 114 & 70 & 8,110 & 8.04 & 0.963 & 25 & 0.510 & $\mathrm{SP}+1 \mathrm{TM}$ & Hyp. Protein & $\mathrm{n} / \mathrm{a}$ \\
\hline 256 & 163 & 17,992 & 8.43 & 0.978 & 35 & 0.916 & $\mathrm{SP}+1 \mathrm{TM}$ & Hyp. Protein & $\mathrm{n} / \mathrm{a}$ \\
\hline 320 & 231 & 26,121 & 10.64 & 0.704 & 27 & 0.695 & $\mathrm{SP}+5 \mathrm{TM}$ & Cons. Hyp. Protein & 39938922 \\
\hline 395 & 812 & 90,281 & 7.15 & 1 & 52 & $0.556^{*}$ & $\begin{array}{l}\mathrm{SP}+1 \mathrm{TM} \\
(\mathrm{o} 783-804 \mathrm{i})^{*}\end{array}$ & Hyp. Protein & $\mathrm{n} / \mathrm{a}$ \\
\hline 413 & 227 & 27,081 & 9.89 & 0.664 & 36 & 0.318 & $\mathrm{SP}+5 \mathrm{TM}$ & Cons. Hyp. Protein & 39938794 \\
\hline 414 & 417 & 48,328 & 9.61 & 0.644 & 33 & $0.447 *$ & $\begin{array}{l}\mathrm{SP}+1 \mathrm{TM} \\
(\mathrm{o} 133-150 \mathrm{i}) *\end{array}$ & ATP-dependent $\mathrm{Zn}$ protease & 39938793 \\
\hline 415 & 450 & 52,577 & 9.58 & 0.950 & 43 & 0.970 & $\mathrm{SP}+6 \mathrm{TM}$ & Dimethyladenosine transferase (EC 2.1.1.-) & 39938792 \\
\hline 432 & 338 & 38,337 & 8.69 & 0.999 & 39 & 0.988 & $\begin{array}{l}\mathrm{SP}+1 \mathrm{TM} \\
(\mathrm{o} 309-331 \mathrm{i})^{*}\end{array}$ & Cons. Hyp. Protein & 39938775 \\
\hline 477 & 321 & 39,079 & 10.06 & 0.573 & 51 & $0.566^{*}$ & $\mathrm{SP}+5 \mathrm{TM}$ & Cons. Hyp. Protein & 39938729 \\
\hline 502 & 413 & 45,871 & 10.58 & 0.999 & 42 & $0.943^{*}$ & $\mathrm{SP}+8 \mathrm{TM}$ & Protein translocase subunit $\mathrm{SecY}$ & 39938706 \\
\hline 530 & 315 & 35,893 & 10.16 & 0.993 & 42 & 0.768 & $\mathrm{SP}+4 \mathrm{TM}$ & Dipeptide $\mathrm{ABC}$ transporter subunit DppB & 39938676 \\
\hline 534 & 272 & 30,875 & 10.16 & 0.768 & 45 & $0.766^{*}$ & $\mathrm{SP}+5 \mathrm{TM}$ & Cons. Hyp. Protein & 39938671 \\
\hline 544 & 226 & 26,434 & 9.87 & 0.611 & 36 & 0.611 & $\mathrm{SP}+5 \mathrm{TM}$ & Cons. Hyp. Protein & 39938662 \\
\hline 561 & 279 & 32,028 & 8.88 & 0.969 & 42 & 0.453 & $\mathrm{SP}+7 \mathrm{TM}$ & Hemolysin III & 39938644 \\
\hline 599 & 164 & 17,679 & 10.16 & 1 & 33 & 0.913 & $\begin{array}{l}\mathrm{SP}+1 \mathrm{TM} \\
(\mathrm{o} 136-158 \mathrm{i}) *\end{array}$ & Antigenic membrane protein (amp) & 39938608 \\
\hline pIV04 & 186 & 21,417 & 10.38 & 0.995 & 38 & 0.991 & $\begin{array}{l}\mathrm{SP}+1 \mathrm{TM} \\
(\mathrm{o} 151-173 \mathrm{i})^{*}\end{array}$ & Cons. Hyp. Protein & 39938944 \\
\hline
\end{tabular}

\footnotetext{
a Annotations are derived from the published AY-WB genome sequence (Bai et al. 2006; GenBank accession numbers CP000061 and CP000065); cons. = conserved and hyp = hypothetical.

b Amino acids (aa).

c Molecular weight in Daltons.

d Isoelectric point.

e Signal peptide (SP) presence probability scores of SignalP v3.0 hidden Markov model (HMM). Proteins with an HMM score $>0.5$ and predicted neural network (NN) cleavage sites between N-terminal 20 and 51 aa are listed (Bendtsen et al. 2004; Nielsen et al. 1997).

${ }^{\mathrm{f}}$ Numbers correspond to the first amino acids of mature proteins.

g NN cleavage site scores. The predictions of SP cleavage sites by HMM and NN were identical, except for those indicated with an asterisk (*).

${ }^{\mathrm{h}}$ Sequences indicated with an asterisk $(*)$ encode proteins that have one transmembrane domain in addition to the SP and are predicted to locate to the exterior of the phytoplasma cell. For these proteins, the location of the transmembrane region (TM) domain from outside (o) to inside (i) is indicated. The portion of the protein N-terminal to the TM region locates toward the exterior of the phytoplasma cell as predicted by TMHMM2.0.

i Accession numbers refer to onion yellows phytoplasma strain M (OY-M) sequences with highest similarities; $n / a=$ no significant similarities.
} 
Table 2. Predicted aster yellows phytoplasma strain witches' broom (AY-WB) secreted proteins (SAP) (56 in total)

\begin{tabular}{|c|c|c|c|c|c|c|c|c|c|c|}
\hline $\begin{array}{l}\text { AY-WB } \\
\text { gene }^{a}\end{array}$ & $\begin{array}{l}\text { SAP } \\
\text { no. }\end{array}$ & $\begin{array}{l}\text { Length } \\
(\text { aa })^{b}\end{array}$ & $\begin{array}{l}\text { MW } \\
(\mathbf{D a})^{\mathbf{c}}\end{array}$ & $\mathbf{I P}^{\mathbf{d}}$ & $\begin{array}{c}\text { SP } \\
\text { score }^{\mathrm{e}}\end{array}$ & $\begin{array}{c}\text { Cleavage } \\
\text { site }^{f}\end{array}$ & $\begin{array}{l}\text { Cleavage } \\
\text { score }\end{array}$ & $\mathbf{N L S}^{\mathrm{h}}$ & Annotation $^{a}$ & $\begin{array}{c}\text { OY } \\
\text { protein }^{\mathrm{i}}\end{array}$ \\
\hline 022 & SAP21 & 125 & 15,165 & 10.73 & 0.991 & 33 & 0.785 & - & Hyp. Protein & $\mathrm{n} / \mathrm{a}$ \\
\hline 032 & SAP05 & 135 & 15,844 & 7.66 & 1 & 33 & 1 & - & Cons. Hyp. Protein & 39939004 \\
\hline 033 & SAP06 & 117 & 13,925 & 10.53 & 1 & 32 & 1 & - & Cons. Hyp. Protein & 39938858 \\
\hline 073 & SAP19 & 186 & 21,909 & 11.37 & 0.98 & 33 & $0.799 *$ & - & Cons. Hyp. Protein & 39938857 \\
\hline 127 & SAP27 & 206 & 23,611 & 8.36 & 0.999 & 35 & 0.793 & - & Hyp. Protein & $\mathrm{n} / \mathrm{a}$ \\
\hline 145 & SAP59 & 154 & 17,765 & 9.90 & 0.828 & 46 & 0.828 & - & Cons. Hyp. Protein & 39939096 \\
\hline 146 & SAP26 & 198 & 14,360 & 10.03 & 0.556 & 44 & $0.524 *$ & - & Cons. Hyp. Protein & 39938886 \\
\hline 148 & SAP25 & 230 & 27,041 & 9.91 & 0.977 & 46 & $0.576^{*}$ & - & Cons. Hyp. Protein & 39938886 \\
\hline 152 & SAP60 & 61 & 7,399 & 10.61 & 0.711 & 47 & 0.711 & - & Hyp. Protein & $\mathrm{n} / \mathrm{a}$ \\
\hline 169 & SAP61 & 192 & 22,132 & 5.85 & 1 & 36 & 1 & - & Cons. Hyp. Protein & 39938972 \\
\hline 189 & SAP36 & 264 & 31,252 & 9.83 & 0.659 & 33 & $0.466^{*}$ & - & Cons. Hyp. Protein & 39938905 \\
\hline 203 & SAP55 & 269 & 31,561 & 4.48 & 0.8 & 32 & 0.8 & - & Cons. Hyp. Protein & 39939062 \\
\hline 212 & SAP39 & 202 & 23,097 & 7.64 & 0.979 & 31 & 0.799 & - & Cons. Hyp. Protein & 39939048 \\
\hline 224 & SAP54 & 124 & 14,480 & 9.77 & 0.997 & 34 & 0.794 & - & Cons. Hyp. Protein & 39938535 \\
\hline 225 & SAP53 & 230 & 26,992 & 8.36 & 0.947 & 39 & $0.607 *$ & - & ATP-dependent $\mathrm{Zn}$ protease & 39939136 \\
\hline 229 & SAP62 & 768 & 89,434 & 9.78 & 0.738 & 28 & $0.572 *$ & - & ATP-dependent $\mathrm{Zn}$ protease & 39938879 \\
\hline 236 & SAP40 & 192 & 22,711 & 7.09 & 0.969 & 32 & 0.789 & - & Cons. Hyp. Protein & 39939028 \\
\hline 237 & SAP41 & 131 & 15,609 & 10.02 & 0.811 & 33 & 0.791 & - & Hyp. Protein & $\mathrm{n} / \mathrm{a}$ \\
\hline 245 & SAP63 & 199 & 23,659 & 9.89 & 1 & 31 & 1 & - & Cons. Hyp. Protein & 39939068 \\
\hline 258 & SAP42 & 77 & 9,247 & 10.23 & 0.983 & 32 & 0.981 & + & Hyp. Protein & $\mathrm{n} / \mathrm{a}$ \\
\hline 259 & SAP43 & 259 & 31,290 & 7.27 & 0.668 & 39 & 0.668 & - & Cons. Hyp. Protein & 39939027 \\
\hline 263 & SAP52 & 291 & 32,560 & 9.08 & 0.616 & 24 & 0.351 & - & SBP ArtI & 39938975 \\
\hline 269 & SAP64 & 235 & 28,073 & 9.86 & 1 & 41 & 0.757 & - & Cons. Hyp. Protein & 39938886 \\
\hline 275 & SAP22 & 715 & 83,908 & 8.42 & 0.951 & 30 & 0.345 & + & ATP-dependent $\mathrm{Zn}$ protease & 39939181 \\
\hline 280 & SAP44 & 87 & 10,357 & 10.64 & 0.813 & 35 & 0.8 & - & Cons. Hyp. Protein & 39939176 \\
\hline 294 & SAP45 & 165 & 19,939 & 10.20 & 0.807 & 33 & 0.796 & - & Hyp. Protein & $\mathrm{n} / \mathrm{a}$ \\
\hline 295 & SAP51 & 106 & 12,524 & 8.91 & 0.564 & 33 & 0.564 & - & Cons. Hyp. Protein & 39939027 \\
\hline 329 & SAP65 & 285 & 33,435 & 9.68 & 0.990 & 40 & $0.789 *$ & - & Cons. Hyp. Protein & 39938930 \\
\hline 339 & SAP49 & 281 & 33,771 & 9.13 & 0.982 & 32 & 0.982 & - & Cons. Hyp. Protein & 39938832 \\
\hline 340 & SAP48 & 65 & 7,626 & 6.50 & 0.981 & 33 & 0.981 & - & Cons. Hyp. Protein & 39938858 \\
\hline 342 & SAP47 & 69 & 8,081 & 10.79 & 0.919 & 40 & $0.599 *$ & - & ATP-dependent $\mathrm{Zn}$ protease & 39939025 \\
\hline 366 & SAP66 & 117 & 13,762 & 9.71 & 0.769 & 33 & 0.769 & - & Hyp. Protein & $\mathrm{n} / \mathrm{a}$ \\
\hline 367 & SAP56 & 100 & 11,987 & 9.71 & 0.795 & 33 & 0.790 & - & Cons. Hyp. Protein & 39938858 \\
\hline 368 & SAP67 & 163 & 19,062 & 9.19 & 0.942 & 33 & 0.648 & - & Cons. Hyp. Protein & 39939063 \\
\hline 369 & SAP68 & 130 & 15,301 & 11.31 & 0.975 & 38 & 0.766 & - & Cons. Hyp. Protein & 39939026 \\
\hline 370 & SAP11 & 121 & 14,360 & 10.03 & 0.999 & 32 & 0.999 & + & Cons. Hyp. Protein & 39939063 \\
\hline 376 & SAP09 & 202 & 23,126 & 8.88 & 0.984 & 31 & 0.8 & - & Cons. Hyp. Protein & 39939048 \\
\hline 387 & SAP08 & 149 & 17,712 & 10.29 & 0.611 & 37 & $0.506^{*}$ & - & Cons. Hyp. Protein & 39938878 \\
\hline 402 & SAP30 & 105 & 12,327 & 10.69 & 0.795 & 35 & 0.758 & + & Cons. Hyp. Protein & 39939176 \\
\hline 433 & SAP50 & 401 & 46,845 & 10.02 & 0.897 & 50 & $0.623 *$ & - & Cons. Hyp. Protein & 39938774 \\
\hline 480 & SAP69 & 338 & 37,578 & 9.89 & 0.569 & 30 & $0.326^{*}$ & - & $\begin{array}{l}\text { Glycerol-3-phosphate dehydr. } \\
\text { [NADP(P)+] (EC 1.1.1.94) }\end{array}$ & 39938727 \\
\hline 529 & SAP70 & 513 & 59,420 & 8.37 & 0.619 & 25 & 0.699 & - & SBP DppA & 39938677 \\
\hline 562 & SAP34 & 311 & 36,578 & 10.22 & 0.672 & 42 & 0.631 & - & Cons. Hyp. Protein & 39938643 \\
\hline 568 & SAP71 & 55 & 6,229 & 10.3 & 0.718 & 37 & 0.718 & - & Hyp. Protein & $\mathrm{n} / \mathrm{a}$ \\
\hline 588 & SAP35 & 348 & 40,170 & 9.31 & 0.818 & 43 & 0.617 & - & SBP NlpA & 39938619 \\
\hline 624 & SAP15 & 380 & 43,443 & 7.95 & 0.999 & 35 & 0.503 & - & SBP ZnuA & 39938578 \\
\hline 640 & SAP13 & 92 & 10,887 & 10.70 & 0.836 & 33 & 0.797 & - & Cons. Hyp. Protein & 39939176 \\
\hline 645 & SAP20 & 268 & 31,443 & 8.98 & 0.924 & 40 & 0.683 & - & Hyp. Protein & $\mathrm{n} / \mathrm{a}$ \\
\hline 667 & SAP72 & 546 & 64,099 & 9.35 & 0.75 & 34 & 0.657 & - & SBP MalE & 39939235 \\
\hline pIO3 & SAP37 & 156 & 18,777 & 9.64 & 0.997 & 36 & $0.562 *$ & - & Cons. Hyp. Protein & 39938945 \\
\hline pIO4 & SAP01 & 197 & 22,459 & 10.38 & 0.753 & 47 & $0.550 *$ & - & Cons. Hyp. Protein & 39938944 \\
\hline pIIO3 & SAP02 & 160 & 18,762 & 6.26 & 0.998 & 36 & $0.428 *$ & - & Cons. Hyp. Protein & 39938945 \\
\hline pIIIO2 & SAP73 & 207 & 24,701 & 5.08 & 0.795 & 37 & 0.795 & - & Hyp. Protein & $\mathrm{n} / \mathrm{a}$ \\
\hline pIIIO4 & SAP74 & 50 & 5,796 & 11.02 & 0.998 & 36 & $0.998 *$ & - & Hyp. Protein & $\mathrm{n} / \mathrm{a}$ \\
\hline pIIIO6 & SAP75 & 123 & 14,807 & 10.54 & 0.983 & 38 & $0.881 *$ & - & Cons. Hyp. Protein & 39938944 \\
\hline pIV03 & SAP76 & 160 & 18,746 & 6.26 & 0.999 & 36 & $0.458 *$ & - & Cons. Hyp. Protein & 39938945 \\
\hline
\end{tabular}

\footnotetext{
a Annotations are derived from the published AY-WB genome sequence (Bai et al. 2006; GenBank accession numbers CP000061, CP000063, CP000064, and CP000065); cons. $=$ conserved, hyp $=$ hypothetical, and SBP $=$ solute binding protein.

b Amino acids (aa).

d Molecular weight in Daltons.

d Isoelectric point.

e Signal peptide (SP) presence probability scores of SignalP v3.0 hidden Markov model (HMM). Proteins with an HMM score $>0.5$ and predicted neural networks (NN) cleavage sites between N-terminal 20 and 51 amino acids are listed (Bendtsen et al. 2004; Nielsen et al. 1997).

${ }^{\mathrm{f}}$ Numbers correspond to the first amino acids of mature proteins.

${ }^{\mathrm{g}} \mathrm{NN}$ cleavage site scores. The predictions of SP cleavage sites by HMM and NN were identical, except for those indicated with an asterisk (*).

${ }^{\mathrm{h}}$ Nuclear localization signals (NLS) were predicted by PSORT and PredictNLS (Cokol et al. 2000) programs. Proteins with NLS are indicated with + and those without with -

${ }^{\mathrm{i}}$ Accession numbers refer to onion yellows phytoplasma strain M (OY-M) sequences with highest similarities; n/a = no significant similarities identified.
} 
(SBP) (Table 2) that are shown to be secreted through the Secdependent pathway in other bacteria (Higgins 2001). This shows again that our SP predictions are consistent with published data. The 56 SAP were unlikely to be lipoproteins, as predicted by LipoP 1.0 (Juncker et al. 2003) and other lipoprotein prediction programs. Therefore, it is probable that, upon secretion, all 56 SAP are released in the extracellular environment of AY-WB.

To investigate whether the 56 SAP have domains that suggest interaction with host cells, we ran the 56 SAP through PSORT and PredictNLS programs (Fig. 1). This resulted in the identification of four SAP with putative nuclear localization signals (NLS), including SAP11 (14 kDa), SAP22 (84 kDa), SAP30 (12 kDa), and SAP42 (9 kDa) (Table 2) (Supplementary Fig. S2). The NLS of SAP 11, 22, and 42 were identified with pSORT and the NLS of SAP30 with PredictNLS using the default settings of the programs. All four SAP have bipartite NLS, and SAP22 also contains a putative monopartite NLS. Therefore, we hypothesized that SAP 11, 22, 30, and 42 are effectors that target plant cell nuclei where they may manipulate plant gene expression.

\section{The gene for SAP11 is located in a PMU region.}

The gene for SAP11, $A Y W B \_370$, is located in a region containing $\operatorname{sig} F, s s b, \operatorname{him} A$, and tra5 genes and a 331-bp sequence repeat (Fig. 2) that are also typically found in PMU of AY-WB (Bai et al. 2006; Hogenhout et al. 2008). AYWB_370 is the first of a series of five genes encoding predicted secreted proteins SAP68, SAP67, SAP56, and SAP66 (Fig. 2; Table 2). The SAP11 PMU-like region contains two open reading frames (ORF) encoding predicted membrane proteins (AYWB371 and AYWB373) and an ORF encoding another predicted secreted protein (SAP09) (Fig. 2). Hypothetical proteins with sequence similarities to these secreted and membrane proteins were found in OY-M and other phytoplasmas (Table 2); however, they had no sequence similarities to domains and proteins with known functions in the nonredundant (nr) GenBank sequence database.

To determine whether the SAP are organized in an operon, we looked for promoter and ribosome-binding sites. The results suggested that AYWB371 and SAP 11, 68, 67, 56, and 66 (Fig. 2) are translated from one transcript. The BPROM and NNPP programs both predicted a transcription start site at nucleotide 387,404 and -10 and -35 promoter boxes upstream of

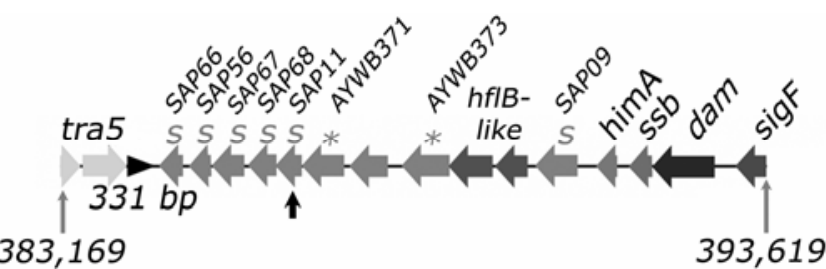

Fig. 2. Gene for secreted aster yellows phytoplasma strain witches' broom (AY-WB) protein SAP11 is located on a potential mobile unit (PMU)-like region adjacent to other genes predicted to encode secreted and membrane-bound proteins. This figure was modified from Hogenhout et al. 2008. The arrows and numbers indicate the first and last nucleotide of the region on the AY-WB chromosome. Genes with annotations have similarities to sequences with known functions in GenBank nr. Gene abbreviations: $\operatorname{sig} F$, sigma factor F; dam, DNA adenine methylase; $s s b$, singlestranded DNA binding protein; himA, DNA binding protein $\mathrm{HU}$; $h f l B$ (two open reading frames $[\mathrm{ORF}]$ ), Zn-dependent DNA protease; tra5 (two ORF), IS3 transposase. The tra5 ORF can produce a single full-length transposase upon a single frame-shift event, and is flanked by a 331-bp repeated sequence also present in other PMUs of AY-WB (Bai et al. 2006). ORF indicated with $\mathrm{s}$ are predicted secreted proteins (SAP), and those labeled with $*$ are membrane proteins based on the presence of transmembrane domains predicted by TMHMM2.0.
AYWB_371 (Fig. 2). Furthermore, putative ribosome-binding sites (gagga or ggaagg) were found immediately upstream of the start sites of all the ORF. Random clustering of guanines (G) in the AY-WB genomes is unlikely, because AY-WB and other phytoplasma genomes are AT-rich $(27 \%$ GC and $73 \%$ AT for AY-WB) (Bai et al. 2006), suggesting that these ribosomebinding sites are genuine. Thus, the gene for SAP11 ( $A Y W B_{-}$ $370)$ is probably part of a larger transcript of approximately 2,800 bp that also contain genes for four other secreted proteins and a membrane protein. If so, these five genes are transcribed simultaneously with SAP11 in planta. Because of the location of the SAP11 gene in a mobile region reminiscent of a pathogenicity island, we focused further research on the functional analysis of SAP11.

\section{SAP11 is expressed in AY-WB-infected plants.}

AY-WB has a broad host range in plants, including China aster (Callistephus chinensis Nees), lettuce (Lactuca sativa L.), Nicotiana benthamiana, tomato (Solanum lycopersicon L.), and Arabidopsis thaliana (S. A. Hogenhout, unpublished data). To determine whether the gene for SAP11 (AYWB_370) is expressed in infected plants, we conducted a two-step reversetranscriptase polymerase chain reaction (RT-PCR) experiment for detection of $A Y W B \_370$ transcripts in symptomatic China aster, lettuce, and $N$. benthamiana plants. In all plants, bands of expected sizes were detected for $A Y W B \_370$ but not in control reactions in which the RT was omitted from the RT reaction (Fig. 3). We used genes for AY-WB GroEL and DnaK as controls in the RT-PCR reactions, because these proteins mediate basic roles in the protein-folding machineries of microbial cells and are generally constitutively expressed (Feldman and Frydman 2000). Bands of expected sizes were detected for the AY-WB groEL and dnaK genes but not in the reactions that did not receive $\mathrm{RT}$, indicating that there was no DNA contamination in the RNA samples (Fig. 3). Together, these data suggest that $A Y W B \_370$ is expressed during AY-WB infection of diverse plants.

\section{SAP11 accumulates in plant cell nuclei in transient expression assays.}

To determine whether SAP11 (Fig. 4A) accumulates in plant cell nuclei, we used the standard Agrobacterium-mediated transient transformation (agroinfiltration) assay developed by Goodin and associates (2002). The construct pGDY:SAP11 that contains the mature SAP11 without SP sequence (Fig. 4B) and pGDY were delivered into $N$. benthamiana cells by agroinfiltration for production of yellow fluorescent protein (YFP) fusions. Confocal laser-scanning microscopy (CLSM) showed that YFP-SAP11 was predominantly localized in plant cell nuclei (Fig. 4C, second panel), whereas YFP alone was distrib-

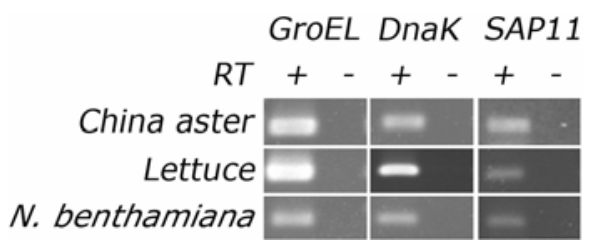

Fig. 3. Gene for aster yellows phytoplasma strain witches' broom (AYWB) protein SAP11 (AYWB_370) is expressed in AY-WB-infected plants A two-step reverse-transcriptase (RT) polymerase chain reaction experiment was conducted with $10 \mathrm{ng}$ of total RNA extracted from AY-WBinfected leaves of China aster, lettuce, and Nicotiana benthamiana as template and specific primers for $A Y W B \_370$. A band of expected size (270 bp) appeared in the AY-WB-infected sample (lane +) but not in the AYWB-infected samples in which the RT was omitted in the RT reaction (lane -). The constitutively expressed AY-WB genes groEL and dnaK served as controls. 
uted equally between the cytoplasm and the nucleus (Fig. 4C, first panel). In conclusion, we validated the bioinformatics predictions that SAP11 targets cell nuclei.

The NLS of SAP11 is required for nuclear targeting.

SAP11 has a bipartite NLS sequence of 18 amino acids (Fig. 4A) (Supplementary Fig. S3). To investigate whether this NLS is required for the localization of this protein to the plant cell nuclei, we deleted a portion of the NLS in SAP11 $\triangle$ NLS1 and the complete NLS in SAP11 $\triangle$ NLS2 (Fig. 4B) and used agroinfiltration to deliver the gene constructs into $N$. benthamiana leaves in side-by-side assays with intact SAP11 and YFP. We decided to introduce these larger deletions, as opposed to single amino acid changes, to ensure disruption of nuclear localization of SAP11. CLSM images revealed that YFP-SAP11 1 NLS1 and YFP-SAP11 $\triangle$ NLS2 distributed equally between plant cell cytoplasm and nucleus, resembling the localization pattern of
YFP alone (Fig. 4C, compare first, third, and fourth panels), whereas YFP-SAP11 located to plant cell nuclei (Fig. 4C, second panel). Because the complete NLS domain was deleted in the SAP11 $\triangle$ NLS2 mutant and a portion of the NLS domain in the SAP11 $\triangle$ NLS1 mutant (Fig. 4A and B), these results suggest that an intact NLS is required for nuclear localization of SAP11.

Nuclear import of SAP11 into plant cell nuclei is dependent on importin $\alpha$.

We used the virus-induced gene silencing (VIGS) assay described by Kanneganti and associates (2007) to evaluate whether SAP11 accumulation in plant nuclei requires importin $\alpha$. Two $N$. benthamiana NbImp $\alpha$ genes, NbImp $\alpha 1$ and NbImp $\alpha 2$, were silenced with the Tobacco rattle virus (TRV)based VIGS system (Ratcliff et al. 2001). Young N. benthamiana plants (five-leaf stage) were infiltrated with mixtures of

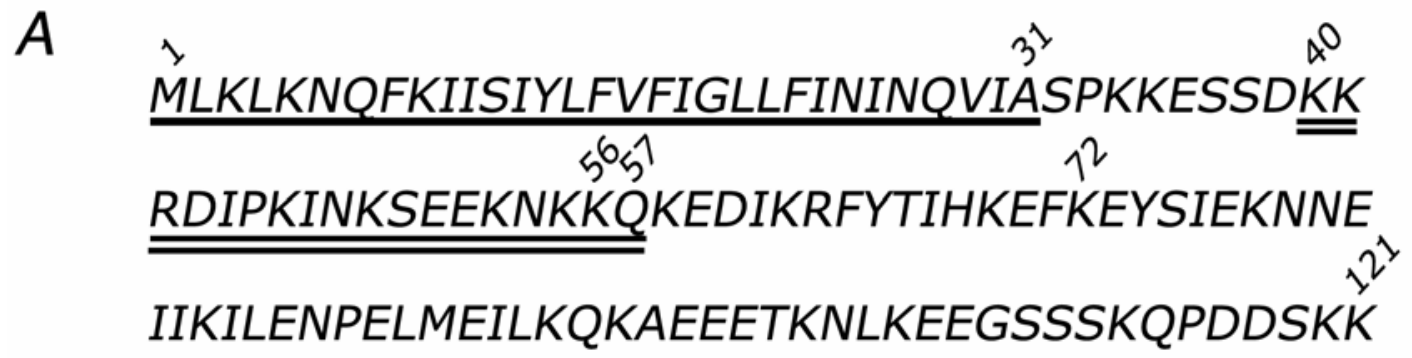

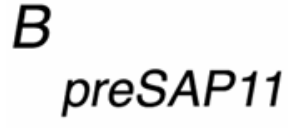

SAP11

$S A P 11 \triangle N L S 1$

$S A P 11 \triangle N L S 2$

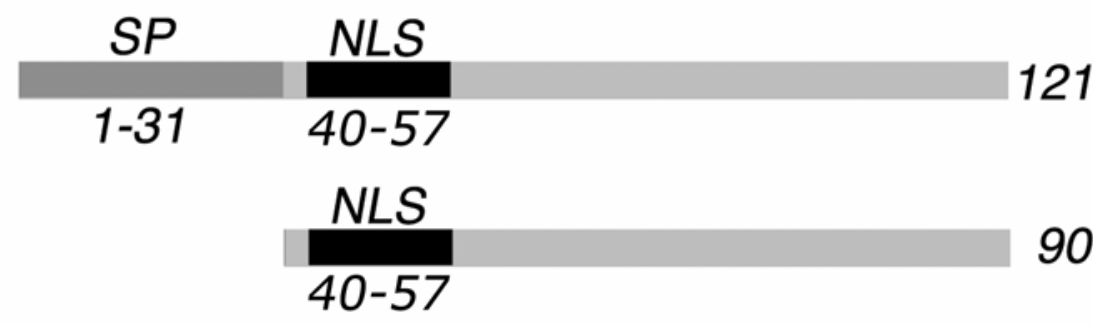

\section{$\Delta 56-72$}

\section{$\Delta 40-57$}
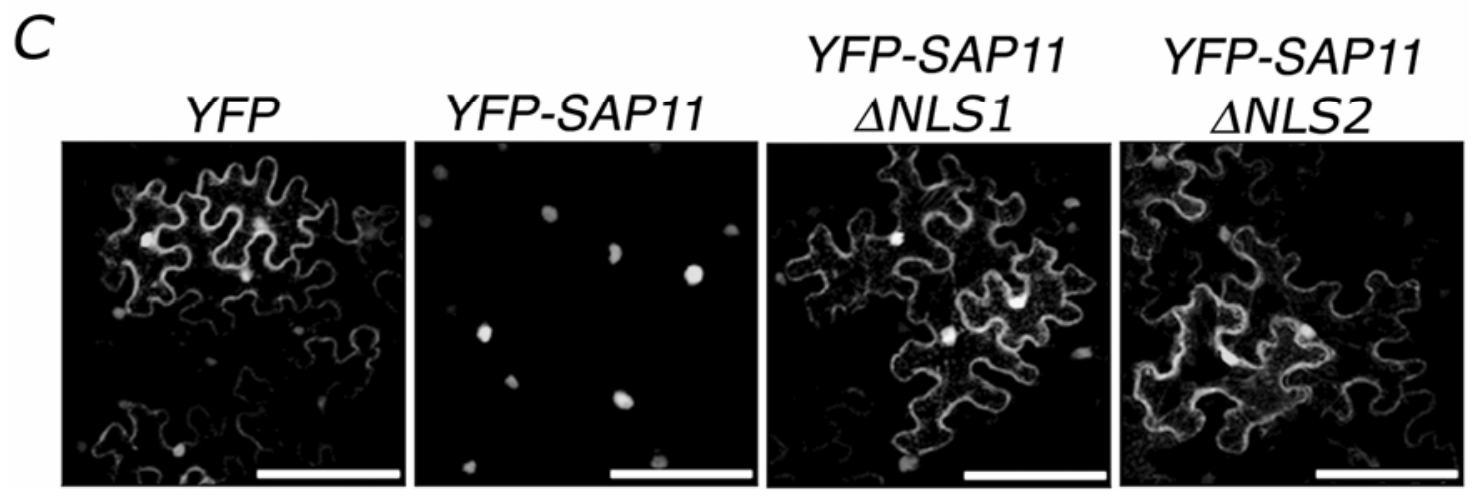

Fig. 4. The nuclear localization signal (NLS) of aster yellows phytoplasma strain witches' broom (AY-WB) protein SAP11 is required for nuclear targeting. A, Sequence of SAP11. The signal peptide (SP) sequence is underlined with a single line and the bipartite nuclear localization sequence (NLS) with a double line. The numbers above the amino acids refer to those depicted in B of this figure. B, Schematic representations of the localization of the NLS and NLS deletions in the SAP11 protein sequence. The numbers indicate the positions of the SP and NLS domains, NLS deletions, and the total lengths of the proteins in amino acids. C, Confocal microscopy images showing nuclear localization of YFP-SAP11 and inhibition of the nuclear targeting of YFP-SAP11 NLS deletion mutants. Bars $=50 \mu \mathrm{m}$. 
Agrobacterium strains carrying pBINTRA6 (the RNA1 of the TRV genome) combined with one of the following plasmid constructs: pTV00 (the RNA2 of the TRV genome), pTV00:PDS (phytoene desaturase gene), pTV00:NbImp $\alpha 1$, and pTV00:NbImp $\alpha 2$. At approximately 3 weeks after infiltration, when young leaves of PDS-silenced plants showed complete bleaching, silencing of the NbImp $\alpha$ genes was verified. RT-PCR results showed significantly lower levels of amplification for one or both of the NbImp $\alpha$ transcripts in the pTV00:NbImp $\alpha$ treated leaves, whereas the amplification levels of the $N$. benthamiana tubulin transcripts were similar in all samples (Fig. 5A). Therefore, these results suggest that the transcription levels of NbImp $\alpha$ genes were reduced in $N$. benthamiana leaves.

To examine whether SAP11 requires NbIMP $\alpha$ for import into nuclei, the NbImpa-silenced plants were infiltrated with Agrobacterium tumefaciens carrying the pGDY:SAP11 construct. At 2 days post infiltration, leaves were examined for localizations by confocal microscopy. Our results showed that YFP-SAP11 shifted to an even distribution between nucleus and cytoplasm in silenced plants (Fig. 5B). In contrast, leaves from empty TRV-infiltrated plants showed accumulation of

$A$

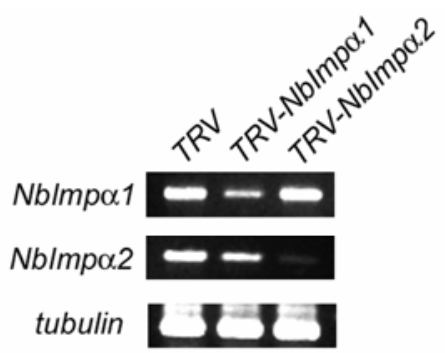

$B$

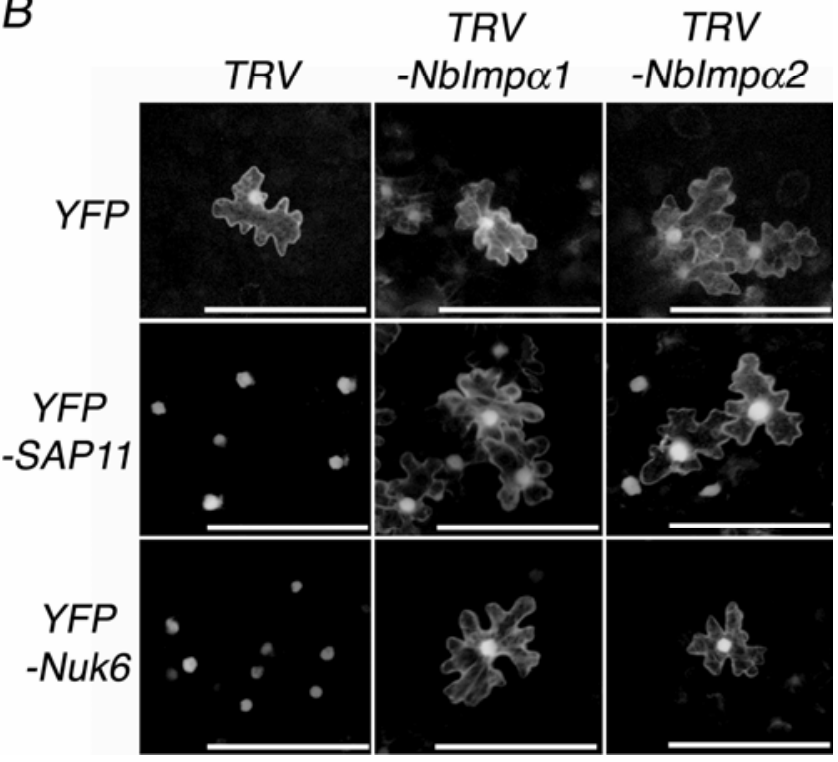

Fig. 5. Nuclear targeting of yellow fluorescence protein (YFP)-aster yellows phytoplasma strain witches' broom (AY-WB) protein SAP11 is dependent on importin $\alpha$. A, Reverse-transcriptase polymerase chain reaction (RT-PCR) results indicating silencing of Nicotiana benthamiana Nbimp $\alpha 1$ and Nbimp $\alpha 2$ expression by virus-induced gene silencing (VIGS) using Tobacco rattle virus (TRV)-based vector constructs TRVNbImpa1 and TRV-NbImpa2. RT-PCR was conducted with primers for NbImpa1 (upper panel), NbImpa2 (middle panel), and tubulin (lower panel) (Table 3). B, Confocal microscopy images showing inhibition of the nuclear targeting of YFP-SAP11 in NbImp $\alpha 1$ and NbImp $\alpha 2$-silenced plants but not in nonsilenced plants treated with empty TRV constructs. YFP-Nuk6 that depends on importin $\alpha$ for nuclear import (Kanneganti et al. 2007) was used as a control. Bars $=100 \mu \mathrm{m}$.
YFP-SAP11 in the nuclei of plant epidermal cells (Fig. 5B). The distribution of the YFP-SAP11 signals resembled those of the positive control nuclear-targeted protein YFP-Nuk6 (Fig. $5 \mathrm{~B}$ ), which is known to be dependent on NbIMP $\alpha$ (Kannaganti et al. 2007). Thus, silencing of NbImpal and NbImp $\alpha 2$ affected the localization pattern of YFP-SAP11. From these results, it appears that YFP-SAP11 is dependent on NbIMP $\alpha 1$ and NbIMP $\alpha 2$ or their close homologs for its nuclear transport.

SAP11 accumulates in the nuclei of infected host plants.

To investigate whether SAP11 locates in the nuclei of plant cells infected with AY-WB, we first developed a polyclonal antibody to purified SAP11 produced as a FLAG-tagged fusion in Escherichia coli. The polyclonal antibody to FLAGSAP11 was raised in mice, and can detect $<10 \mathrm{ng}$ of purified FLAG-SAP11 (Supplementary Fig. S4A and B). The SAP11 antibody did not detect $100 \mathrm{ng}$ of FLAG-EPI5, a recombinant FLAG-tagged protein of Phytophthora infestans (M. Tian and S. Kamoun, unpublished), in the Western blot analysis, indicating that the polyclonal antibodies target mostly the SAP11 portion and not the FLAG tag of the FLAG-SAP11 fusion.

We then used the SAP11 antibody combined with goat antimouse Alexa Fluor 488 for immunofluorescence CLSM (iCLSM) to determine the subcellular localization of SAP11 in AY-WB-infected China aster plants that have high numbers of phytoplasmas in the phloem cells of sink tissues (Ammar and Hogenhout 2006). The iCLSM results showed green fluorescence of nuclei of AY-WB-infected China aster plants but not of healthy China aster plants (Fig. 6). Even though phytoplasmas are phloem-limited, SAP11 was detected in many different cell types beyond the phloem, including nonvascular mesophyll and trichome (leaf hair) cells of the analyzed sink tissues (Fig. 6, arrows, and inset). Thus, based on the iCLSM results, we conclude that the SAP11 is produced and targets nuclei of various cell types in China aster plants during AY-WB infection. SAP11 might migrate beyond the phloem because, in sink tissues, proteins smaller than $40 \mathrm{kDa}$ can be unloaded from the phloem and move to adjacent cells (Imlau et al. 1999).

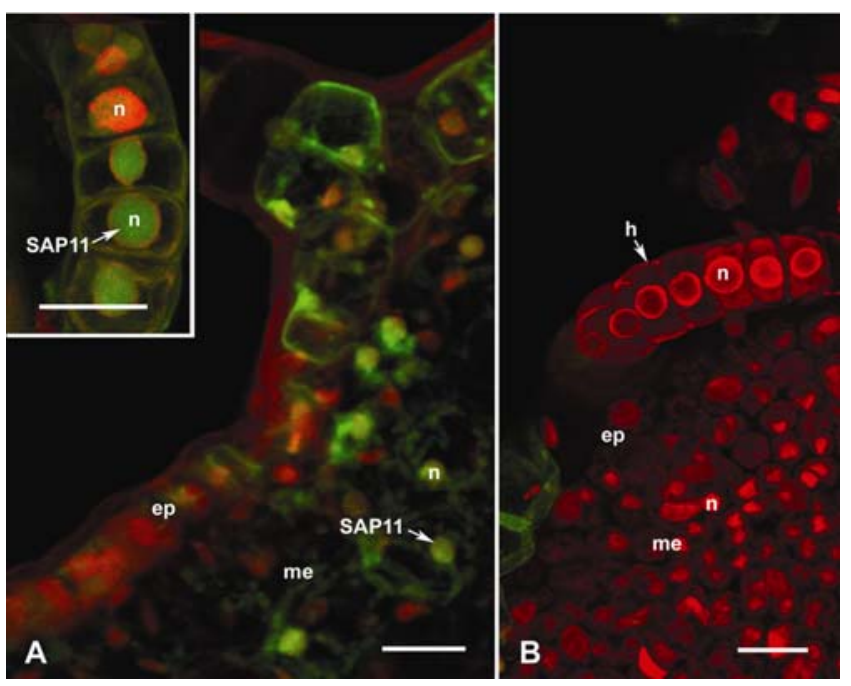

Fig. 6. Aster yellows phytoplasma strain witches' broom (AY-WB) protein SAP11 located to the nuclei of plant cells beyond the phloem. A and inset, SAP11 detected in the nuclei (n), with an Alexa-fluor-conjugated antibody (green fluorescence), in sections of AY-WB-infected China aster leaves. Inset shows the detection of SAP11 in nuclei of a trichome. B, Sections from healthy China aster leaves that were processed in the same way as A (negative control). In both A and B, propidium iodide (red fluorescence) specifically stains nucleic acids. Hence, nuclei fluoresce bright red. Abbreviations: ep, epidermis; h, leaf hair; me, mesophyll. Bars $=20 \mu \mathrm{m}$. 


\section{DISCUSSION}

The completion of the genome sequences of four phytoplasmas, the $\mathrm{Ca}$. Phytoplasma asteris strains AY-WB and OY-M, one strain of $\mathrm{Ca}$. Phytoplasma australiense, and the agent of apple proliferation disease $\mathrm{Ca}$. Phytoplasma mali (Bai et al. 2006; Kube et al. 2008; Oshima et al. 2004; Tran-Nguyen et al. 2008), offers unique opportunities for uncovering pathogenicity mechanisms of these enigmatic and poorly studied bacterial pathogens. Here, we combined computational analyses with wet lab functional assays to identify and characterize the secreted candidate effector protein SAP11. First, we identified 56 candidate effector proteins based on the presence of an $\mathrm{N}$ terminal SP sequence. These effectors were hypothesized to be secreted inside host cells, where they manipulate various processes in the plant and animal hosts. Indeed, we showed that phytoplasma effector SAP11 contains a eukaryotic bipartite NLS that is functional in plant cells. Most remarkably, we used immunocytology to demonstrate that SAP11 localizes in nuclei of aster plants infected with AY-WB. Finally, in N. benthamiana, nuclear localization of SAP11 required a host factor, importin $\alpha$. In summary, these results support the view that, similar to other plant pathogens, phytoplasmas secrete effector proteins that manipulate host processes.

Because we observed phytoplasmas near the nuclei of protophloem cells (Ammar and Hogenhout 2006), our initial hypothesis was that phytoplasmas secrete proteins that target nuclei to manipulate these protophloem cells, thereby inducing some of the typical symptoms seen in phytoplasma-infected plants. However, immunofluorescence microscopy experiments detected SAP11 beyond the phloem tissue in mesophyll and other cell types (Fig. 6), suggesting that SAP11 moves out of the phloem into adjacent tissues. This finding is consistent with current knowledge of intercellular transport of macromolecules in plants. Imlau and associates (1999) showed that green fluorescent protein (GFP) specifically produced in phloem cells under control of the AtSUC2 promoter in Arabidopsis can unload from the phloem into mesophyll cells and other cell types of developing (sink) tissues, including young rosette leaves, petals, anthers, and roots, whereas this postphloem transport of GFP was not detected in fully developed (source) tissues. Indeed, the size exclusion limits of plasmodesmata change during organ development. The size exclusion limits of sink tissue plasmodesmata range between 10 and 40 $\mathrm{kDa}$, whereas those of source tissues are smaller (Imlau et al. 1999). Interestingly, the majority of secreted AY-WB proteins (51 of 56), including SAP11 and SAP30, are smaller than 40 $\mathrm{kDa}$, indicating that most secreted protein of AY-WB may move out of the phloem and target developing tissues of plants. This is consistent with the appearance of symptoms in predominantly developing tissues of phytoplasma-infected plants. For instance, typical phytoplasma-induced symptoms are witches' broom (clustering of branches) of developing tissues, phyllody (retrograde metamorphosis of the floral organs to the condition of leaves), virescence (green coloration of non-green flower parts), bolting (growth of elongated stalks), and the formation of bunchy fibrous secondary roots. Our data also conform to a report showing expression of phytoplasma Sec proteins, which are required for protein secretion, in plant phloem (Kakizawa et al. 2001).

Our SP and transmembrane predictions are consistent with published data. SP predictions were validated by the presence of sequences similar to five SBP among the 56 SAP. SBP are ArtI (AYWB_263), DdpA (AYWB_529), NlpA (AYWB_588), ZnuA (AYWB_624), and MalE (AYWB_667) (Table 2). These SBP are part of ATP-binding cassette (ABC) transporters and are secreted through the Sec-dependent pathway in other bac- teria (Higgins 2001). As expected, the genes for these proteins are located adjacent to genes of $\mathrm{ABC}$ transporter systems in the AY-WB chromosome (Bai et al. 2006). SBP are frequently involved in bacterial virulence (Higgins 2001). For example, the SBP Sc76 of another insect-transmitted mollicute pathogen, Spiroplasma citri, is important for infection of the salivary glands and transmission by the leafhopper Circulifer haematoceps (Boutareaud et al. 2004). Many SBP, including Sc76, are lipoproteins that remain attached to the bacterial membrane through a lipid anchor at the first conserved cysteine residue of the mature peptide (Hayashi and Wu 1990). None of the AY-WB SBP have this conserved cysteine residue at the +1 position. SAP30 has a cysteine residue at the +2 position of the SP cleavage site; however, this protein is unlikely to be a lipoprotein as predicted by LipoP 1.0 (Juncker et al. 2003) and other lipoprotein prediction programs. Therefore, it is probable that, upon secretion, all 56 SAP are released in the extracellular environment of AY-WB. The accuracy of our SP predictions is also supported by the presence of AYWB_599, which is similar to phytoplasma Amps, among the 20 membrane proteins (Table 1). Amps possess a cleavable SP (Barbara et al. 2002), are secreted by the Sec-dependent translocation system (Kakizawa et al. 2004), and are abundant cell-surface proteins (Milne et al. 1995). Amp of OY-W interacts with microfilaments, including actin, myosin heavy chain, and myosin light chain, of insect vectors, but not of non-OY-transmitting insects, suggesting that Amp determines insect specificity (Susuki et al. 2006) and, hence, is a virulence protein.

Effectors that carry NLS and translocate to plant cell nuclei have been reported in several gram-negative plant-pathogenic bacteria. These include the type III effector proteins PopP2 of Ralstonia solanacearum (Deslandes et al. 2003) and the large AvrBs3/pthA family of Xanthomonas spp. (Lahaye and Bonas 2001). The AvrBs3 family effectors bind double-stranded DNA sequences (Yang et al. 2000) and are capable of transcriptional activation (Zhu et al. 1998). More recently, it was shown that AvrBs3 Xanthomonas campestris pv. vesicatoria activates the pepper resistance gene $B s 3$ and the master regulator of cell size gene upa 20 directly by binding to their promoter regions (Kay et al. 2007; Römer et al. 2007). In X. oryzae pv. oryzae, the AvrBs3/pthA effectors, named transcription activator-like (TAL) effectors, induce several rice genes that make this plant more susceptible to the bacterium (Sugio et al. 2007; Yang et al. 2006). The type III effectors HsvG and HsvB of Pantoea agglomerans were also shown to target nuclei, bind doublestranded DNA, and activate transcription (Nissan et al. 2006). The present study suggests that gram-positive bacteria have also evolved effector proteins with eukaryotic motifs that target plant cell nuclei.

Phytoplasmas are dependent on phloem-feeding insects for dispersal. Hence, it benefits the dispersal and reproductive success of phytoplasmas to make plants more attractive to the insect vectors. Plants with witches' broom, phyllody, and virescence symptoms generally have more suitable leaves for leafhopper feeding and oviposition (Peterson 1973; Schultz 1973). Indeed, the leafhopper Macrosteles quadrilineatus lays almost twice the number of eggs on phytoplasma-infected plants compared with healthy plants (Beanland et al. 2000). Furthermore, female $M$. quadrilineatus leafhoppers reared on aster yellows phytoplasma-infected plants lived, on average, 8 days longer than those reared on phytoplasma-free plants (Beanland et al. 2000). Aster yellows phytoplasma infections also enable the survival and development of leafhopper species on nonhost plants (Maramorosch 1958; Purcell 1988; Severin 1946). These observations make it reasonable to speculate that phytoplasmas produce effector proteins that affect plant development, such as manipulation of young shoots and leaves, to 
transform plants into more suitable feeding and oviposition hosts for leafhoppers. Therefore, it is possible that the function of the SAP11 effector is to alter developmental processes in plants rather than suppressing host defenses as frequently observed in type III secretion system effectors of gram-negative bacteria (Buttner and Bonas 2006; Chisholm et al. 2006; Grant et al. 2006; Mudgett 2005; Toth and Birch 2005). Current research is aimed at identifying the biochemical activity of SAP11 in plant nuclei and testing this hypothesis.

The data presented in this article lead to a model of SAP11 action during phytoplasma infection of plant tissue. We propose that SAP11 is an effector protein, similar to type III effector proteins of gram-negative plant pathogens. SAP11 is secreted by the intracellular AY-WB directly inside phloem cells and then is transported to mesophyll and other plant cells where it targets nuclei to perhaps affect the expression of various genes, including transcription factors. SAP11 may function alone or in a complex with other secreted proteins encoded in the SAP11 PMU-like pathogenicity island or elsewhere in the AYWB genome.

More generally, our proposal that phytoplasmas secrete effector proteins that function inside host cells brings about some exciting questions. These pathogens have an intriguing life cycle that includes intracellular replication in plants and insects. Furthermore, they have a broad plant host range of up to 1,000 plant species worldwide. The extent to which phytoplasmas rely on effectors to manipulate their diverse plant and animal hosts remains to be determined; however, with the availability of phytoplasma genome sequences, this subject can now be studied. It would be interesting to investigate the extent to which phytoplasma-secreted proteins are conserved between different strains and species, and whether they show evidence of positive selection as noted for other plant pathogen effectors. In conclusion, we feel that extending the concept of effectors to the phytoplasmas points to novel research strategies with the renewed hope for unraveling the pathogenicity mechanisms of these fascinating bacteria.

\section{MATERIALS AND METHODS}

\section{Bacterial strains and maintenance.}

AY-WB strain was collected from diseased lettuce plants in Celeryville, $\mathrm{OH}\left(41.00^{\circ} \mathrm{N}, 82.45^{\circ} \mathrm{W}\right)$ in 1998 (Zhang et al. 2004). We maintained the AY-WB culture by serial transmission to China aster (Callistephus chinensis) plants by aster leafhoppers (M. quadrilineatus L.) in greenhouse and growth chambers.

A. tumefaciens GV3101 (Holsters et al. 1980) was routinely grown at $28^{\circ} \mathrm{C}$ in Luria-Bertani (LB) media supplemented with appropriate antibiotics (Sambrook et al. 1989). E. coli XL1blue was used for general cloning purpose and routinely grown at $37^{\circ} \mathrm{C}$ in $\mathrm{LB}$ media.

\section{Data mining for phytoplasma candidate effector proteins.}

The PosSet consisted of 46 experimentally verified mollicutes secreted proteins (Edman et al. 1999) provided by $\AA$. Wieslander and the NegSet of 323 mollicutes cytoplasmic proteins extracted from the SwissProt database (Gasteiger et al. 2003). The SignalP v3.0 program (Bendtsen et al. 2004) was used to predict the presence of N-terminal SP within the predicted ORF of the fully sequenced AY-WB chromosome and four plasmids (Bai et al. 2006) (GenBank accession numbers CP000061 to CP000065). Subsequently, ORF containing additional transmembrane domains predicted by TMHMM2.0 program (Krogh et al. 2001) in addition to the N-terminal SP were removed, generating the SAP dataset. ORF were annotated using BLAST (Basic Local Alignment Search Tool) algorithm
(Altschul et al. 1997) searches against the GenBank nr database. The presence of NLS was predicted with pSORT (Nakai and Horton 1999) and PredictNLS (Cokol et al. 2000). For promoter prediction on the SAP11 region, we used two promoter prediction programs: BPROM, the bacterial sigma70 promoter recognition program in SoftBerry (Softberry, Inc. Mount Kisco, NY, U.S.A.); and the Berkeley Drosophila Genome Project (BDGP) Neural Network Promoter Prediction (NNPP) version 2.2 for prokaryotes (Reese 2000, 2001). We looked manually for putative ribosome-binding sites (gagga boxes) upstream of start sites of each predicted ORF.

\section{Detection of AY-WB transcripts in plants.}

To obtain AY-WB-infected China aster, lettuce, and N. benthamiana, approximately $50 \mathrm{M}$. quadrilineatus leafhoppers that had 1 week of access to AY-WB-infected China aster plants 2 weeks prior were confined to insect cages containing four healthy, 3- to 4-week-old China aster, lettuce, and N. benthamiana plants. The leafhoppers were removed 1 week later. Plants generally showed witches' broom (China aster and lettuce) (Zhang et al. 2004), yellowing, and stunting (all plants) symptoms at 2 to 3 weeks after the first day of exposure to AYWB-infected leafhoppers. At this time, leaves were harvested and immediately frozen in liquid nitrogen and were kept at $-80^{\circ} \mathrm{C}$ until further processing. A two-step RT-PCR experiment was used to investigate whether the gene $\left(A Y W B \_370\right)$ for the NLS-containing candidate effector SAP11 of AY-WB was expressed during infection of China aster, lettuce, and $N$. benthamiana. Total RNA was isolated from leaves of healthy and AY-WB-infected plants following the instructions of the ToTALLY RNA kit (Ambion, Austin, TX, U.S.A.). Total RNA samples were treated with DNA-free kit (Ambion) to degrade residual genomic DNA. The RT reaction was conducted with Superscript II RT (Invitrogen) following the manufacturer's procedures and the reverse primers for $A Y W B \_370$ (AYWB370R), groEL, and $d n a K$ (Table 3). To ensure that RNA samples were free of DNA contamination, the RT was omitted from the RT reaction in control reactions. Subsequently, samples were amplified with the forward and reverse primers for groEL, dnaK, and AYWB370FpG and AYWB370R for $A Y W B \_370$ (Table 3) using Taq DNA polymerase (Qiagen, Hilden, Germany) following the manufacturer's protocol.

\section{In planta localization assays of YFP fusions.}

To determine the subcellular localization of phytoplasma proteins in plants, we fused the NLS-containing candidate effector proteins of AY-WB to the C-terminus of YFP and examined the localization of the yellow signal from the recombinant proteins in plants. The ORF excluding the portion encoding SP of candidate effector proteins were amplified with gene-specific primers (Table 3 ) complementary to the $5^{\prime}$ and $3^{\prime}$ ends of each respective ORF and including restriction site overhangs for cloning into the pGDY vector (Goodin et al. 2002) with AY-WB genomic DNA as template. The YFP: SAP11 1 NLS1 and YFP:SAP11 1 NLS2 were generated by amplification with AYWB370F_pGD and AYWB370R_pGD primers (Table 3) with corresponding pGR106::SAP11 and pGR106::SAP11 $\Delta$ NLS2 constructs as templates (pGR106 cloning procedures are described below). All PCR products were ligated into pGDY by standard procedures and transformed into A. tumefaciens GV3101 cells by electroporation. The cells were allowed to grow for 2 days at $28^{\circ} \mathrm{C}$ on LB agar plates supplemented with kanamycin at $50 \mu \mathrm{g} \mathrm{ml}^{-1}$. The sequences of three clones for each construct were verified to ensure that they were in fusion with YFP, and one of each was selected for in planta studies. 
$N$. benthamiana plants were maintained in a greenhouse at ambient temperatures of 22 to $25^{\circ} \mathrm{C}$. Plants were infiltrated at the six-leaf stage with individual GV3101 colonies following procedures described elsewhere (Goodin et al. 2002). Briefly, GV3101 suspension cultures were adjusted to an optical density at $600 \mathrm{~nm}\left(\mathrm{OD}_{600}\right)$ of 0.6 to 1.0 in MES buffer $(10 \mathrm{mM}$ $\mathrm{MgCl}_{2}, 10 \mathrm{mM} \mathrm{MES}, \mathrm{pH}$ 5.6), after which acetosyringone was added at a final concentration of $150 \mu \mathrm{M}$. Cultures were incubated at room temperature for $3 \mathrm{~h}$ before infiltration into two leaves per plant. The infiltrated leaves were harvested at 48 to $72 \mathrm{~h}$ after infiltration and examined by laser-scanning confocal microscopy using a Leica TCS SP2 filter-free spectral confocal and multiphoton microscope.

\section{$N$. benthamiana importin $\alpha$ silencing experiments.}

To determine the role of importin proteins in transporting phytoplasma proteins into plant nuclei, we inhibited the expression of $N$. benthamiana importin $\alpha$ genes (Kanneganti et al. 2007) by using TRV-mediated VIGS (Liu et al. 2002; Ratcliff et al. 2001). The importin $\alpha$ genes were amplified from the $N$. benthamiana cDNA library (Kanneganti et al. 2007) using gene-specific primers designed to contain overhangs with appropriate restriction recognition sites for cloning into the pTV00 vector, which allows production of the RNA2 portion of the TRV genome (Ratcliff et al. 2001). N. benthamiana leaves were simultaneously infiltrated with $A$. tumefaciens GV3101 carrying the pTV00 constructs and A. tumefaciens GV3101 carrying the pBINTRA6 construct. The latter construct allows production of the RNA1 portion of the TRV genome (Ratcliff et al. 2001). Construct pTV00:PDS was used as a positive control to monitor and visualize the onset of gene silencing, because silencing of PDS induces photobleaching of green leaves (Kumagai et al. 1995; Ratcliff et al. 2001; Ruiz et al. 1998). We used the empty pTV00 vector as a negative con- trol to monitor phenotypes resulting from TRV infection. At approximately 3 weeks after infiltration, young leaves of PDSsilenced plants showed complete bleaching. At this time, silencing of the NbImp $\alpha$ genes was verified by collection of leaf samples from all infiltrated plants and subsequent total RNA extraction and RT-PCR. Two plants for each construct were assayed. To ensure that only the endogenous gene was being amplified, RT-PCR primers were designed to anneal externally to the DNA fragment cloned in pTV00 (Table 3). The matching upper leaves of TRV-infiltrated $N$. benthamiana plants that showed silencing of the importin $\alpha$ genes were infiltrated with $A$. tumefaciens GV3101 carrying the pGDY constructs as described above. After $48 \mathrm{~h}$, leaves were harvested and examined by using laser scanning confocal microscopy as described above. A pGDY construct carrying the gene of Phytophthora infestans Nuk6, which depends on importin $\alpha$ for nuclear import (Kanneganti et al. 2007), was used as control.

\section{Antibody production and Western blot hybridizations.}

Western blot hybridization with customized antibody was used for monitoring production of phytoplasma candidate effector protein SAP11 in plants by iCLSM. The SAP11 ORF excluding the SP sequence was PCR amplified using gene-specific primers (Table 3 ). The amplified product was cloned into the pFLAG-ATS vector (Sigma-Aldrich) and electro-transformed into $E$. coli XL1-blue cells.

For protein production, overnight cultures grown in ampicillin $\mathrm{LB}$ at $50 \mu \mathrm{g} \mathrm{ml}^{-1}$ were diluted at 1:10 and grown to an $\mathrm{OD}_{600}$ of 0.6. Expression was induced through adding $0.4 \mu \mathrm{M}$ isopropyl- $\beta$-D-thiogalactoside. Cultures were collected after 6 $\mathrm{h}$ and centrifuged at $6,000 \mathrm{rpm}$ at $4^{\circ} \mathrm{C}$ for $30 \mathrm{~min}$. The supernatants were filtered through a $0.45-\mu \mathrm{m}$ syringe filter, and the FLAG-fused proteins were affinity purified using columns containing anti-FLAG M2 agarose affinity gel (Sigma-Aldrich,

Table 3. Primers used in this study

\begin{tabular}{|c|c|}
\hline Primer name & Primer sequences $\left(5^{\prime} \text { to } 3^{\prime}\right)^{a}$ \\
\hline \multicolumn{2}{|l|}{ pFLAG-ATS cloning } \\
\hline AYWB370FpF & gcgAAGCTTTCACCTAAAAAAGAATCTAGTG \\
\hline AYWB370R & ATTTAgcggcegcggtaccTTATTTTTTAGAATCATCAGGTTG \\
\hline \multicolumn{2}{|l|}{ pGDY cloning } \\
\hline AYWB370F_pGD & GCGAGATCTTCACCTAAAAAAGAATCTAGTG \\
\hline AYWB370R_pGD & GCTGTCGACTTATTTTTTAGAATCATCAGGTTGTTTTGAAG \\
\hline AYWB275F_pGD & GCGCTCGAGCTGCTACTACCAGAAAACCGC \\
\hline AYWB275R_pGD & GCGGGATCCTTATTCTGCATAAACATTATCCTC \\
\hline AYWB402F_pGD & GCGAGATCTACTTGTAATAATAATTCTGAAGG \\
\hline AYWB402R_pGD & GCGGTCGACTTATTTTTTCTTTTTATTAGGTTTTG \\
\hline AYWB258F_pGD & GCGAGATCTATAAATAATTTAAATGATGAAAATTC \\
\hline AYWB258R_pGD & GCGgtcgacTTATCTAАТTTTTTTTААТTTTАТАТСАССАС \\
\hline \multicolumn{2}{|l|}{ Importin $\alpha$ silencing } \\
\hline NbImpa1-pGDR-F & GCGctcgagccATGTCGCTGAGGCCGAATTCGAGAAC \\
\hline NbImp $\alpha 1-p G D R-R$ & GCGggatccGGGGACACACTCCAGCTTCAATAACAGC \\
\hline NbImp $\alpha 2-p G D R-F$ & GCGctcgagccATGTCTCTGAGACCAAGTGCTAGGACGG \\
\hline NbImp $\alpha 2-p G D R-R$ & GCGggatceAGGAGACGGATGCATGAGGAGCTCAACCA \\
\hline Totub-F1 (tubulin) & GCTGCTGTAACAAGGTTTGCTTTAATTCG \\
\hline Totub-R1 (tubulin) & CCAGCATCACACTGCACAGTTCACTTC \\
\hline \multicolumn{2}{|l|}{ Generation of mutants ${ }^{\mathrm{b}}$} \\
\hline AYWB370-5-F & GCGatcgatGTCACCTAAAAAAGAATCTAGTG \\
\hline AYWB370-5-R & aatattcTTTGTTTTTTTCTTCTGATTTATTAATTTTCG \\
\hline AYWB370-3-F & gaaaaaacaaaGAATATTCAATTGAAAAAAATAATG \\
\hline AYWB370-3-R & GCGgcggcegcggatccTTATTTTTTAGAATCATCAGGTTG \\
\hline AYWB370-F2 & GCGatcgatGTCACCTAAAAAAGAATCTAGTGATAAAGAAGATATAAAAAGATTTTATAC \\
\hline \multicolumn{2}{|c|}{ Detection of AY-WB transcripts ${ }^{\mathrm{c}}$} \\
\hline GroEL f & TAAAGCTGCTATTACTGAGGG \\
\hline GroEL_r & CAAAGCAGAGATAGAAGCAGC \\
\hline DnaK_f & TATTTCAGGAAGTGGTGCCC \\
\hline DnaK_r & GTCTACTACTTCGTCTTGAGG \\
\hline
\end{tabular}


St. Louis). Elution fractions containing purified FLAG-tagged SAP11 were combined and concentrated. Protein concentration was measured using Bradford reagents (Bio-Rad, Hercules, CA, U.S.A.).

For antibody production, $25 \mu \mathrm{g}$ of purified FLAG-tagged SAP11 was mixed with Freund's incomplete adjuvant (SigmaAldrich) at the ratio of $1: 1$ and used for each subcutaneous injection into 6-week-old female balb/c mice. A boost was given 3 weeks after the first injection. Another 3 weeks later, 100- $\mu \mathrm{l}$ blood samples were collected and tested for antibody titer. Mice were anesthetized and blood was collected. Antisera were collected by centrifugation and stored at $-20^{\circ} \mathrm{C}$ until further uses.

For Western blot analysis, protein samples were ground in equal portions (wt/vol) of Laemmli sample buffer (Bio-Rad) containing $5 \% \beta$-mercaptoethanol and heated at $100^{\circ} \mathrm{C}$ for 5 min. Proteins were loaded in 10 to $15 \%$ gels and run in $1 \times$ Trisglycine-sodium dodecyl sulfate (SDS) buffer for $1 \mathrm{~h}$ at $120 \mathrm{~V}$. Proteins separated by SDS polyacrylamide gel electrophoresis were stained by Coomassie Brilliant Blue R-250 (Bio-Rad) or electrophoretically transferred to nitrocellulose membranes (Bio-Rad). The membrane was equilibrated in phosphate-buffered saline-Tween (PBST) $\left(2 \mathrm{mM} \mathrm{KH_{2 }} \mathrm{PO}_{4}, 8 \mathrm{mM} \mathrm{Na} \mathrm{HPO}_{4}\right.$, $0.14 \mathrm{M} \mathrm{NaCl}, 2 \mathrm{mM} \mathrm{KCl}$, and $0.1 \%$ Tween-20) for $15 \mathrm{~min}$ and blocked in 5\% nonfat milk in PBST for $1 \mathrm{~h}$. Incubations with primary antibodies were performed overnight at room temperature, followed by $3 \mathrm{~h}$ of incubation with anti-mouse immunoglobulin G alkaline phosphatase (AP)-conjugated secondary antibody (Sigma-Aldrich). The color development was performed with AP Conjugated Substrate Kit (Bio-Rad).

\section{iCLSM.}

Preparation of hand-cut sections of plant samples for iCLSM followed the protocols described in Ammar and Hogenhout (2005) and Ammar and Hogenhout (2008). Leaves from young shoots of AY-WB-infected or healthy China aster leaves were fixed in $1 \%$ paraformaldehyde in $0.1 \mathrm{M}$ phosphate buffer, $\mathrm{pH} 7.4,+0.1 \%$ Triton $\mathrm{X}-100$ for 4 to $5 \mathrm{~h}$ at $4{ }^{\circ} \mathrm{C}$. The fixed leaves were then washed in $0.1 \mathrm{M}$ phosphate buffer, $\mathrm{pH}$ 7.4 , dehydrated in a gradient of ethanol up to $100 \%$, followed by $100 \%$ xylene, infiltrated with paraffin at $60^{\circ} \mathrm{C}$, and then properly oriented and embedded in $60^{\circ} \mathrm{C}$ paraffin in flat embedding molds (Electron Microscopy Sciences, Fort Washington, PA, U.S.A.). Thick sections (6 to $8 \mu \mathrm{m}$ ) picked up on Tissue Tack microscope slides (Polysciences, Eppelheim, Germany) were deparaffinized in xylene, rehydrated in a graded ethanol series, and air dried.

For iCLSM, sections were immersed in blocking buffer (PBST $+10 \%$ normal goat serum) for $30 \mathrm{~min}$ and incubated with antiserum to SAP11 diluted at 1:50 for $3 \mathrm{~h}$ at room temp in incubation buffer (PBST $+1 \%$ normal goat serum). The sections were washed in PBST, incubated $1 \mathrm{~h}$ with a 1:600 dilution of the secondary antibody conjugated to Alexa Fluor 488 (Molecular Probes, Eugene, OR, U.S.A.), washed in PBST, and then incubated for $5 \mathrm{~min}$ with $3 \mathrm{nM}$ solution of the fluorescent nucleic acid stain propidium iodide (Molecular Probes) before the final wash in PBST. In contrast to the green fluorescence of Alexa Fluor, propidium iodide stains cell nuclei red, which was very helpful in identifying various tissues during microscopic examination. Specimens were mounted on microscope slides in Gel-Mount (Biomeda, Theres, Germany) and examined by the confocal laser scanning microscope (Leica TCS SP).

\section{ACKNOWLEDGMENTS}

We thank D. M. Hartzler and A. D. Strock in the Department of Entomology; J. Bos and D. M. Kinney in the Department of Plant Pathology at The Ohio State University (OSU)-OARDC; and M. Tian, currently at
Michigan State University, for technical support and constructive discussions; M. Goodin at the Department of Plant Pathology, University of Kentucky, Lexington 40546, U.S.A. for help with the confocal microscopy experiments shown in Figure 1; and A. Sugio for critical reading of the manuscript. This research was supported by OSU-OARDC Research Enhancement Competitive Grant 2001-052, Marie Curie International Reintegration Grant MIRG-14-CT-2007-046570, and Gatsby Charitable Foundation fellowship awarded to S. Hogenhout; and the OSU-OARDC Research Enhancement Competitive Grant 2003-170 awarded to X. Bai. S. Kamoun is supported by the Gatsby Charitable Foundation.

\section{LITERATURE CITED}

Altschul, S. F., Madden, T. L., Schaffer, A. A., Zhang, J., Zhang, Z., Miller, W., and Lipman, D. J. 1997. Gapped BLAST and PSI-BLAST: A new generation of protein database search programs. Nucleic Acids Res. 25:389-3402.

Aly, K. A., and Baron, C. 2007. The VirB5 protein localizes to the T-pilus in Agrobacterium tumefaciens. Microbiology 153:3766-3775.

Ammar, E. D., and Hogenhout, S. A. 2005. Immunofluorescence confocal laser scanning microscopy as a reliable method for studying the distribution of mollicutes in vector leafhoppers (Cicadellidae: Hemiptera) and in host plants. Ann. Entomol. Soc. Am. 98:820-826.

Ammar, E. D., and Hogenhout, S. A. 2006. Mollicutes associated with arthropods and plants. Pages 97-118 in: Insect Symbiosis, Vol. II. B Kostas and T Miller, eds. CRC Press, Taylor \& Francis Group, Boca Raton, FL, U.S.A.

Ammar, E. D., and Hogenhout, S. A. 2008. A neurotropic route for Maize mosaic virus (Rhabdoviridae) in its planthopper vector Peregrinus maidis. Virus Res. 131:77-85.

Angelini, E., Filippin, L., Michielini, C., Bellotto, D., and Borgo, M. 2006. High occurrence of Flavescence doree phytoplasma early in the season on grapevines infected with grapevine yellows. Vitis 45:151-152.

Angot, A., Vergunst, A., Genin, S., and Peeters, N. 2007. Exploitation of eukaryotic ubiquitin signaling pathways by effectors translocated by bacterial type III and type IV secretion systems. PLoS Pathog. 3:e3.

Bai, X., Zhang, J., Ewing, A., Miller, S. A., Jancso Radek, A., Shevchenko, D. V., Tsukerman, K., Walunas, T., Lapidus, A., Campbell, J. W., and Hogenhout, S. A. 2006. Living with genome instability: The adaptation of phytoplasmas to diverse environments of their insect and plant hosts. J. Bacteriol. 188:3682-3696.

Balish, M. F. 2006. Subcellular structures of mycoplasmas. Front. Biosci. 11:2017-2027.

Barbara, D. J., Morton, A., Clark, M. F., and Davies, D. L. 2002. Immunodominant membrane proteins from two phytoplasmas in the aster yellows clade (chlorante aster yellows and clover phyllody) are highly divergent in the major hydrophilic region. Microbiology-Sgm. 148:157167.

Beanland, L., Hoy, C. W., Miller, S. A., and Nault, L. R. 2000. Influence of aster yellows phytoplasma on the fitness of aster leafhopper (Homoptera:Cicadellidae). Ann. Entomol. Soc. Am. 93:271-276.

Bendtsen, J. D., Nielsen, H., von Heijne, G., and Brunak, S. 2004. Improved prediction of signal peptides: SignalP 3.0. J. Mol. Biol. 340:783795.

Berho, N., Duret, S., and Renaudin, J. 2006. Absence of plasmids encoding adhesion-related proteins in non-insect-transmissible strains of Spiroplasma citri. Microbiology 152:873-886.

Bertaccini, A. 2007. Phytoplasmas: Diversity, taxonomy, and epidemiology. Front. Biosci. 12:673-689.

Boutareaud, A., Danet, J. L., Garnier, M., and Saillard, C. 2004. Disruption of a gene predicted to encode a solute binding protein of an $\mathrm{ABC}$ transporter reduces transmission of Spiroplasma citri by the leafhopper Circulifer haematoceps. Appl. Environ. Microbiol. 70:3960-3967.

Bricker, A. L., Cywes, C., Ashbaugh, C. D., and Wessels, M. R. 2002. NAD+-glycohydrolase acts as an intracellular toxin to enhance the extracellular survival of group A streptococci. Mol. Microbiol. 44:257-269.

Bukhalid, R. A., Chung, S. Y., and Loria, R. 1998. nec1, a gene conferring a necrogenic phenotype, is conserved in plant-pathogenic Streptomyces spp. and linked to a transposase pseudogene. Mol. Plant-Microbe Interact. 11:960-967.

Burger, A., Graefen, I., Engemann, J., Niermann, E., Pieper, M., Kirchner, O., Gartemann, K. H., and Eichenlaub, R. 2005. Identification of homologues to the pathogenicity factor Pat-1, a putative serine protease of Clavibacter michiganensis subsp. michiganensis. Microbiol. Res. 160:417-427.

Buttner, D., and Bonas, U. 2006. Who comes first? How plant pathogenic bacteria orchestrate type III secretion. Curr. Opin. Microbiol. 9:193200.

Chisholm, S. T., Coaker, G., Day, B., and Staskawicz, B. J. 2006. Host- 
microbe interactions: Shaping the evolution of the plant immune response. Cell 124:803-814.

Cokol, M., Nair, R., and Rost, B. 2000. Finding nuclear localization signals. EMBO (Eur. Mol. Biol. Organ.) Rep. 1:411-415.

Deslandes, L., Olivier, J., Peeters, N., Feng, D. X., Khounlotham, M., Boucher, C., Somssich, I., Genin, S., and Marco, Y. 2003. Physical interaction between RRS1-R, a protein conferring resistance to bacterial wilt, and PopP2, a type III effector targeted to the plant nucleus. Proc. Natl. Acad. Sci. U.S.A. 100:8024-8029.

Desveaux, D., Singer, A. U., and Dangl, J. L. 2006. Type III effector proteins: Doppelgangers of bacterial virulence. Curr. Opin. Plant Biol. 9:376-382.

Ding, Z., Atmakuri, K., and Christie, P. J. 2003. The outs and ins of bacterial type IV secretion substrates. Trends Microbiol. 11:527-535.

Duduk, B., and Bertaccini, A. 2006. Corn with symptoms of reddening: New host of stolbur phytoplasma. Plant Dis. 90:1313-1319.

Edman, M., Jarhede, T., Sjostrom, M., and Wieslander, A. 1999. Different sequence patterns in signal peptides from mycoplasmas, other grampositive bacteria, and Escherichia coli: A multivariate data analysis. Proteins 35:195-205.

Feldman, D. E., and Frydman, J. 2000. Protein folding in vivo: The importance of molecular chaperones. Curr. Opin. Struct. Biol. 10:26-33.

Garnier, M., Foissac, X., Gaurivaud, P., Laigret, F., Renaudin, J., Saillard, C., and Bove, J. M. 2001. Mycoplasmas, plants, insect vectors: A matrimonial triangle. C. R. Acad. Sci. III 324:923-928.

Gasteiger, E., Gattiker, A., Hoogland, C., Ivanyi, I., Appel, R. D., and Bairoch, A. 2003. ExPASy: The proteomics server for in-depth protein knowledge and analysis. Nucleic Acids Res. 31:3784-3788.

Goodin, M. M., Dietzgen, R. G., Schichnes, D., Ruzin, S., and Jackson, A. O. 2002. pGD vectors: Versatile tools for the expression of green and red fluorescent protein fusions in agroinfiltrated plant leaves. Plant J. 31:375-383.

Grant, S. R., Fisher, E. J., Chang, J. H., Mole, B. M., and Dangl, J. L. 2006. Subterfuge and manipulation: Type III effector proteins of phytopathogenic bacteria. Annu. Rev. Microbiol. 60:425-449.

Hayashi, S., and Wu, H. C. 1990. Lipoproteins in bacteria. J. Bioenerg. Biomembr. 22:451-471.

Healy, F. G., Wach, M., Krasnoff, S. B., Gibson, D. M., and Loria, R. 2000. The txtAB genes of the plant pathogen Streptomyces acidiscabies encode a peptide synthetase required for phytotoxin thaxtomin A production and pathogenicity. Mol. Microbiol. 38:794-804.

Higgins, C. F. 2001. ABC transporters: Physiology, structure and mechanism--an overview. Res. Microbiol. 152:205-210.

Hogenhout, S. A., and Loria, R. 2008. Virulence mechanisms of grampositive plant pathogenic bacteria. Curr. Opin. Plant Biol. 11:449-456.

Hogenhout, S. A., Oshima, K., Ammar, E.-D., Kakizawa, S., Kingdom, H. N., and Namba, S. 2008. Phytoplasmas: Bacteria that manipulate plants and insects. Mol. Plant Pathol. 9:403-423.

Holsters, M., Silva, B., Van Vliet, F., Genetello, C., De Block, M., Dhaese, P., Depicker, A., Inzé, D., Engler, G., Villarroel, R., Van Montagu, M., and Schell, J. 1980. The functional organization of the nopaline A. tumefaciens plasmid pTiC58. Plasmid 3:212-230.

Imlau, A., Truernit, E., and Sauer, N. 1999. Cell-to-cell and long-distance trafficking of the green fluorescent protein in the phloem and symplastic unloading of the protein into sink tissues. Plant Cell 11:309-322.

Jin, Q, and He, S. Y. 2001. Role of the Hrp pilus in type III protein secretion in Pseudomonas syringae. Science 294:2556-2558.

Jovic, J., Cvrkovic, T., Mitrovic, M., Krnjajic, S., Redinbaugh, M. G., Pratt, R. C., Gingery, R. E., Hogenhout, S. A., and Tosevski, I. 2007. Roles of stolbur phytoplasma and Reptalus panzeri (Cixiinae, Auchenorrhyncha) in the epidemiology of Maize redness in Serbia. Eur. J. Plant Pathol. 118:85-89.

Juncker, A. S., Willenbrock, H., Von Heijne, G., Brunak, S., Nielsen, H., and Krogh, A. 2003. Prediction of lipoprotein signal peptides in gramnegative bacteria. Protein Sci. 12:1652-1662.

Kakizawa, S., Oshima, K., Kuboyama, T., Nishigawa, H., Jung, H., Sawayanagi, T., Tsuchizaki, T., Miyata, S., Ugaki, M., and Namba, S. 2001. Cloning and expression analysis of Phytoplasma protein translocation genes. Mol. Plant-Microbe Interact. 14:1043-1050.

Kakizawa, S., Oshima, K., Nishigawa, H., Jung, H. Y., Wei, W., Suzuki, S. Tanaka, M., Miyata, S., Ugaki, M., and Namba, S. 2004. Secretion of immunodominant membrane protein from onion yellows phytoplasma through the Sec protein-translocation system in Escherichia coli. Microbiology 150:135-142.

Kamoun, S. 2006. A catalogue of the effector secretome of plant pathogenic oomycetes. Annu. Rev. Phytopathol. 44:41-60.

Kannan, T. R., and Baseman, J. B. 2006. ADP-ribosylating and vacuolating cytotoxin of Mycoplasma pneumoniae represents unique virulence determinant among bacterial pathogens. Proc. Natl. Acad. Sci. U.S.A. 103:6724-6729.
Kanneganti, T., Bai, X., Win, J., Meulia, T., Goodin, M. M., Kamoun, S and Hogenhout, S. A. 2007. A functional assay for nuclear trafficking in plants. Plant J. 50:149-158.

Kay, S., Hahn, S., Marois, E., Hause, G., and Bonas, U. 2007. A bacterial effector acts as a plant transcription factor and induces a cell size regulator. Science 318:648-651.

Killiny, N., Batailler, B., Foissac, X., and Saillard, C. 2006. Identification of a Spiroplasma citri hydrophilic protein associated with insect transmissibility. Microbiology 152:1221-1230.

Krogh, A., Larsson, B., von Heijne, G., and Sonnhammer, E. L. 2001. Predicting transmembrane protein topology with a hidden Markov model: Application to complete genomes. J. Mol. Biol. 305:567-580.

Kube, M., Schneider, B., Kuhl, H., Dandekar, T., Heitmann, K., Migdoll, A. M., Reinhardt, R., and Seemüller, E. 2008. The linear chromosome of the plant-pathogenic mycoplasma 'Candidatus Phytoplasma mali'. BMC Genomics 26:306.

Kumagai, M. H., Donson, J., della-Cioppa, G., Harvey, D., Hanley, K., and Grill, L. K. 1995. Cytoplasmic inhibition of carotenoid biosynthesis with virus-derived RNA. Proc. Natl. Acad. Sci. U.S.A. 92:1679-1683.

Lahaye, T., and Bonas, U. 2001. Molecular secrets of bacterial type III effector proteins. Trends Plant Sci. 6:479-485.

Lee, I. M., Davis, R. E., and Gundersen-Rindal, D. E. 2000. Phytoplasma: Phytopathogenic mollicutes. Annu. Rev. Microbiol. 54:221-255.

Liu, Y., Schiff, M., and Dinesh-Kumar, S. P. 2002. Virus-induced gene silencing in tomato. Plant J. 31:777-786.

Loria, R., Kers, J., and Joshi, M. 2006. Evolution of plant pathogenicity in Streptomyces. Annu. Rev. Phytopathol. 44:469-487.

Mackey, D., and McFall, A. J. 2006. MAMPs and MIMPs: Proposed classifications for inducers of innate immunity. Mol. Microbiol. 61:13651371.

Madden, J. C., Ruiz, N., and Caparon, M. 2001. Cytolysin-mediated translocation (CMT): A functional equivalent of type III secretion in grampositive bacteria. Cell 104:143-152.

Maramorosch, K. 1958. Beneficial effect of virus-diseased plants of nonvector insects. Tijdschr. Plantenziekten 64:383-391.

Marzachi, C., and Bosco, D. 2005. Relative quantification of chrysanthemum yellows (16Sr I) phytoplasma in its plant and insect host using real-time polymerase chain reaction. Mol. Biotechnol. 30:117-127.

Menne, K. M., Hermjakob, H., and Apweiler, R. 2000. A comparison of signal sequence prediction methods using a test set of signal peptides. Bioinformatics 16:741-742.

Milne, R. G., Ramasso, E., Lenzi, R., Masenga, V., Sarindu, N., and Clark, M. F. 1995. Preembedding and postembedding immunogold labeling and electron-microscopy in plant host tissues of 3 antigenically unrelated Mlos-Primula Yellows, Tomato Big Bud and Bermudagrass White Leaf. Eur. J. Plant Pathol. 101:57-67

Mudgett, M. B. 2005. New insights to the function of phytopathogenic bacterial type III effectors in plants. Annu. Rev. Plant Biol. 56:509-531.

Mueller, C. A., Broz, P., and Cornelis, G. R. The type III secretion system tip complex and translocon. Mol. Microbiol. 68:1085-1095.

Nakai, K., and Horton, P. 1999. PSORT: A program for detecting the sorting signals of proteins and predicting subcellular localization. Trends Biochem. Sci. 24:34-35.

Nielsen, H., Engelbrecht, J., Brunak, S., and von Heijne, G. 1997. A neural network method for identification of prokaryotic and eukaryotic signal peptides and prediction of their cleavage sites. Int. J. Neural Syst. 8:581-599.

Nissan, G., Manulis-Sasson, S., Weinthal, D., Mor, H., Sessa, G., and Barash, I. 2006. The type III effectors HsvG and HsvB of gall-forming Pantoea agglomerans determine host specificity and function as transcriptional activators. Mol. Microbiol. 61:1118-1131.

Oshima, K., Kakizawa, S., Nishigawa, H., Jung, H. Y., Wei, W., Suzuki, S., Arashida, R., Nakata, D., Miyata, S., Ugaki, M., and Namba, S. 2004. Reductive evolution suggested from the complete genome sequence of a plant-pathogenic phytoplasma. Nat. Genet. 36:27-29.

Peterson, A. G. 1973. Host plant and aster leafhopper relationships. Proc. North Cent. Branch Entomol. Soc. Am. 28:66-70.

Purcell, A. H. 1988. Increased survival of Dalbulus maidis, a specialist on maize, on non-host plants infected with mollicute plant pathogens. Entomol. Exp. Appl. 46:187-196.

Ratcliff, F., Martin-Hernandez, A. M., and Baulcombe, D. C. 2001. Technical advance. Tobacco rattle virus as a vector for analysis of gene function by silencing. Plant J. 25:237-245.

Razin, S., Yogev, D., and Naot, Y. 1998. Molecular biology and pathogenicity of mycoplasmas. Microbiol. Mol. Biol. Rev. 62:1094-1156.

Reese, M. G. 2000. Computational prediction of gene structure and regulation in the genome of Drosophila melanogaster. Ph.D. thesis, University of California-Berkeley/University of Hohenheim, Stuttgart, Germany.

Reese, M. G. 2001. Application of a time-delay neural network to pro- 
moter annotation in the Drosophila melanogaster genome. Comput. Chem. 26:51-56.

Römer, P., Hahn, S, Jordan, T., Strauß, T., Bonas, U., and Lahaye, T. 2007. Plant pathogen recognition mediated by promoter activation of the pepper $b s 3$ resistance gene. Science 318:645-648.

Rosch, J. W., and Caparon, M. G. 2005. The ExPortal: An organelle dedicated to the biogenesis of secreted proteins in Streptococcus pyogenes. Mol. Microbiol. 58:959-968.

Rottem, S. 2003. Interaction of mycoplasmas with host cells. Physiol. Rev. 83:417-432.

Rudzinska-Langwald, A., and Kaminska, M. 1999. Cytopathological evidence for transport of phytoplasma in infected plants. Acta Soc. Bot. Pol. Pol. Tow. Bot. 68:261-266.

Ruiz, M. T., Voinnet, O., and Baulcombe, D. C. 1998. Initiation and maintenance of virus-induced gene silencing. Plant Cell 10:937-946.

Sambrook, J., Fritsch, E. F., and Maniatis, T. 1989. Molecular Cloning: A Laboratory Manual. Cold Spring Harbor Laboratory Press, Cold Spring Harbor, NY, U.S.A.

Schneider, G., and Fechner, U. 2004. Advances in the prediction of protein targeting signals. Proteomics 4:1571-1580.

Schultz, G. A. 1973. Plant resistance to aster yellows. Proc. North Cent. Branch Entomol. Soc. Am. 28:93-99.

Severin, H. H. P. 1946. Longevity, or life histories, of leafhopper species on virus-infected and on healthy plants. Hilgardia 17:121-137.

Streten, C., and Gibb, K. S. 2006. Phytoplasma diseases in sub-tropical and tropical Australia. Australas. Plant Pathol. 35:129-146.

Sugio, A., Yang, B., Zhu, T., and White, F. F. 2007. Two type III effector genes of Xanthomonas oryzae pv. oryzae control the induction of the host genes OsTFIIA $\gamma 1$ and $O s T F X 1$ during bacterial blight of rice. Proc. Natl. Acad. Sci. U.S.A. 104:10720-10725.

Suzuki, S., Oshima, K., Kakizawa, S., Arashida, R., Jung, H. Y., Yamaji, Y., Nishigawa, H., Ugaki, M., and Namba, S. 2006. Interaction between the membrane protein of a pathogen and insect microfilament complex determines insect-vector specificity. Proc. Natl. Acad. Sci. U.S.A. 103:4252-4257.

Torto, T. A., Li, S., Styer, A., Huitema, E., Testa, A., Gow, N. A., van West, P., and Kamoun, S. 2003. EST mining and functional expression assays identify extracellular effector proteins from the plant pathogen Phy- tophthora. Genome Res. 13:1675-1685.

Toth, I. K., and Birch, P. R. 2005. Rotting softly and stealthily. Curr. Opin. Plant Biol. 8:424-429.

Tran-Nguyen, L. T., Kube, M., Schneider, B., Reinhardt, R., and Gibb, K. S. 2008. Comparative genome analysis of 'Candidatus Phytoplasma australiense' (subgroup tuf-Australia I; $r p-A$ ) and ' $C a$. Phytoplasma asteris' strains OY-M and AY-WB. J. Bacteriol. 190:3979-3991.

Vinatzer, B. A., Teitzel, G. M., Lee, M. W., Jelenska, J., Hotton, S. Fairfax, K., Jenrette, J., and Greenberg, J. T. 2006. The type III effector repertoire of Pseudomonas syringae pv. syringae B728a and its role in survival and disease on host and non-host plants. Mol. Microbiol. 62:26-44.

Weintraub, P. G., and Beanland, L. 2006. Insect vectors of phytoplasmas. Annu. Rev. Entomol. 51:91-111.

Weisburg, W. G., Tully, J. G., Rose, D. L., Petzel, J. P., Oyaizu, H., Yang, D., Mandelco, L., Sechrest, J., Lawrence, T. G., Van Etten, J., Maniloff, J., and Woese, C. R. 1989. A phylogenetic analysis of the mycoplasmas: Basis for their classification. J. Bacteriol. 171:6455-6467.

Woese, C. R. 1987. Bacterial evolution. Microbiol. Rev. 51:221-271.

Yang, B., Zhu, W., Johnson, L. B., and White, F. F. 2000. The virulence factor AvrXa7 of Xanthomonas oryzae pv. oryzae is a type III secretion pathway-dependent nuclear-localized double-stranded DNA-binding protein. Proc. Natl. Acad. Sci. U.S.A. 97:9807-9812.

Yang, B., Sugio A., and White F. F. 2006. Os 8 N3 is a host disease-susceptibility gene for bacterial blight of rice. Proc. Natl. Acad. Sci. U.S.A. 103:10503-10508.

Zhang, J. H., Hogenhout, S. A., Nault, L. R., Hoy, C. W., and Miller, S. A. 2004. Molecular and symptom analyses of phytoplasma strains from lettuce reveal a diverse population. Phytopathology 94:842-849.

Zhu, W., Yang, B., Chittoor, J. M., Johnson, L. B., and White, F. F. 1998. AvrXa10 contains an acidic transcriptional activation domain in the functionally conserved $\mathrm{C}$ terminus. Mol. Plant-Microbe Interact. 11:824-832.

\section{AUTHOR-RECOMMENDED INTERNET RESOURCE}

PSORT www server: psort.ims.u-tokyo.ac.jp 